This work is licensed under a Creative Commons Attribution 3.0 License.

\title{
Two new species of shrimp of the Indo-West Pacific genus Hamodactylus Holthuis, 1952 (Crustacea: Decapoda: Palaemonidae)
}

\author{
Ivona HORKÁ ${ }^{1,4}$, Charles H.J.M. FRANSEN ${ }^{2}$ \& Zdeněk ĎURIŠ ${ }^{3, *}$ \\ ${ }^{1,3}$ Department of Biology and Ecology, and Institute of Environmental Technologies, \\ University of Ostrava, Chittussiho 10, CZ-71000 Ostrava, Czech Republic. \\ ${ }^{2}$ Department of Taxonomy \& Systematics, Naturalis Biodiversity Center, \\ P.O. Box 9517, 2300 RA Leiden, The Netherlands. \\ ${ }^{4}$ Department of Ecology, Charles University, Viničná 7, CZ-12844 Prague, Czech Republic. \\ *Corresponding author: zdenek.duris@,osu.cz \\ ${ }^{1}$ ivona.horka@osu.cz \\ ${ }^{2}$ charles.fransen@naturalis.nl \\ ${ }^{1}$ urn:1sid:zoobank.org:author:CCA47494-EA9C-46D9-B579-90772B584F35 \\ ${ }^{2}$ urn:1sid:zoobank.org:author:08C8BF56-A737-4B4F-BC80-56333AE6AB3A \\ ${ }^{3}$ urn:Isid:zoobank.org:author:0CF5D3F9-9663-4B76-BF91-713D9BE50BC3
}

\begin{abstract}
Two new alcyonacean-associated species, Hamodactylus paraqabai sp. nov. from Papua New Guinea and the Great Barrier Reef and H. pseudaqabai sp. nov. from Indonesia and Malaysia, are described and illustrated. To evaluate the status of the new species and their relationship within the genus Hamodactylus Holthuis, 1952, we combined morphology and phylogenetic analyses based on the cytochrome $c$ oxidase subunit I (COI) mitochondrial gene. Both new species are closely related, with their mutual genetic divergence reaching 3-4\%. They are further most related to Hamodactylus aqabai Bruce \& Svoboda, 1983, originally described from the Red Sea. Both new species are distinguished from all other congeners by the presence of multiple teeth distally on the cutting edges of the fingers of the first pereiopods, and, in the case of $H$. paraqabai sp. nov., by a full reduction of the fixed finger on the second pereiopod chela. In H. pseudaqabai sp. nov. the finger is greatly reduced to a small but distinct stub, and the telson bears only a single pair of dorsal spines, as in H. aqabai. A key for the identification of all six currently known species is proposed.
\end{abstract}

Key words. Palaemonidae, Hamodactylus paraqabai sp. nov., Hamodactylus pseudaqabai sp. nov., coral associates, identification key.

Horká I., Fransen C.H.J.M. \& Duriš Z. 2016. Two new species of shrimp of the Indo-West Pacific genus Hamodactylus Holthuis, 1952 (Crustacea: Decapoda: Palaemonidae). European Journal of Taxonomy 188: 1-26. http://dx.doi.org/10.5852/ejt.2016.188

\section{Introduction}

The genus Hamodactylus Holthuis, 1952 comprises at present four Indo-West Pacific species associated with corals, i.e., H. aqabai Bruce \& Svoboda, 1983, H. boschmai Holthuis, 1952, H. noumeae Bruce, 1970 
and H. macrophthalmus Fransen \& Rauch, 2013. Hamodactylus aqabai, H. boschmai and H. noumeae are associated with octocorallian soft corals (Alcyonacea) (Bruce 1970b, 1981, 1983; Bruce \& Svoboda 1983), whereas H. macrophthalmus was reported from hexacorallian hard corals (Scleractinia) (Fransen \& Rauch 2013).

A series of specimens was recently obtained from material collected during research campaigns to Indonesia (1990), Malaysia (Semporna Marine Ecological Expedition, 2012), Australia (CReefs Lizard Island Expedition, the Great Barrier Reef, 2010) and Papua New Guinea (Papua Niugini Expedition, Madang, 2012). Those specimens, initially assigned to $H$. aqabai, were revealed to contain two new species, different from specimens of $H$. aqabai obtained by us from the northern Red Sea. The separation of those two new species is supported by morphological characters and molecular analyses. Both the new species are described and illustrated here, and their distinctions from H. aqabai and from other known congeners are discussed.

\section{Material and methods}

The following abbreviations are used in the methods and descriptions of taxa:

$\mathrm{BI}=$ Bayesian Inference

$\mathrm{COI}=$ mitochondrial gene cytochrome $c$ oxidase subunit I

$\mathrm{fcn}=$ field collection number

ML = Maximum Likelihood

$\mathrm{PCR}=$ Polymerase chain reaction

PoCL $=$ Post orbital carapace length

$\operatorname{spm}(\mathrm{s})=\operatorname{specimen}(\mathrm{s})$

$\mathrm{RL}=$ rostrum length, measured from the posterior orbital margin to the distal end of the most anterior tooth of the rostrum

$\mathrm{SD}=$ standard deviation

$\mathrm{TL}=$ total length of the body measured from tip of the rostrum to the distal end of the telson (latter without posterior spines)

Abbreviated names of institutions:

MNHN $=$ Muséum national d'Histoire naturelle, Paris, France

MSS = Marine Science Station, Aqaba, Jordan

MTQ $=$ Museum of Tropical Queensland, Townsville, Australia

RMNH = Naturalis Biodiversity Center (formerly Rijksmuseum van Natuurlijke Historie), Leiden, The Netherlands

$\mathrm{UO}=$ University of Ostrava, Czech Republic

\section{Sample collection}

The shrimps of the genus Hamodactylus were collected in the Indo-West Pacific region (Lizard Island, Australia, 2010; Sabah, Malaysia, 2010; Indonesia, 1990, 1994, 1996, 2010; Madang Bay, Papua New Guinea, 2012) and in the Red Sea (Aqaba, Jordan, 2009) by hand net during scuba diving. Complete specimens were preserved in $80 \%$ ethanol for morphological studies and samples of tissues (abdominal muscle, pleopods or eggs) for molecular analysis in $96-99 \%$ ethanol. Voucher specimens are stored in the crustacean collections of RMNH, MTQ, MNHN and UO.

\section{DNA extraction, amplification and sequencing}

Total genomic DNA was extracted from the shrimps' abdominal muscle tissues, pleopods or eggs using the DNeasy Blood \& Tissue Isolation Kit (QIAGEN, Hilden, Germany) according to the manufacturer's instructions. Polymerase chain reactions were performed in $25 \mu \mathrm{l}$ volumes containing $2 \mu \mathrm{l}$ DNA template, 
HORKÁ I. et al., Two new species of Hamodactylus (Palaemonidae)

Table 1. Species used in the molecular analysis, with details on sampling locations, GenBank accession numbers $(\mathrm{COI})$ and voucher identification numbers of specimens examined. $\mathrm{AU}=$ Australia; $\mathrm{IN}=$ Indonesia; JO = Jordan; MA = Malaysia; $\mathrm{PNG}=$ Papua New Guinea; $*=$ sequences obtained from GenBank.

\begin{tabular}{cccc}
\hline Taxa & $\begin{array}{c}\text { Sampling } \\
\text { location }\end{array}$ & $\begin{array}{c}\text { GenBank } \\
\text { access. nr. }\end{array}$ & Voucher spec. reg. nr. \\
\hline Palaemonidae & & & \\
H. aqabai Bruce \& Svoboda, 1983 & Aqaba (JO) & KR088750 & UO Aq09-55 \\
H. boschmai Holthuis, 1952 & Sabah (MA) & KC633172** & RMNH.CRUS.D.53814 \\
H. boschmai Holthuis, 1952 & Sabah (MA) & KC633173* & RMNH.CRUS.D.53831 \\
H. boschmai Holthuis, 1952 & Sabah (MA) & KC633174* & RMNH.CRUS.D.53786 \\
H. macrophthalmus Fransen \& Rauch, 2013 & Sulawesi (IN) & KC633177* & RMNH.CRUS.D.55048 \\
H. noumeae Bruce, 1970b & Sabah (MA) & KC633176* & RMNH.CRUS.D.53812 \\
H. paraqabai sp. nov., holotype & Madang (PNG) & KR088751 & MNHN-IU-2013-11092 \\
H. paraqabai sp. nov., paratype & Madang (PNG) & KR088752 & MNHN-IU-2013-11090 \\
H. paraqabai sp. nov. & Lizard Is. (AU) & KR088753 & MTQ-33208 \\
H. paraqabai sp. nov. & Lizard Is. (AU) & KR088754 & MTQ-33218 \\
H. pseudaqabai sp. nov., holotype & Sulawesi (IN) & KT598272 & RMNH.CRUS.D.57195 \\
H. pseudaqabai sp. nov. & Sabah (MA) & KC633175* & RMNH.CRUS.D.53969 \\
Outgroup & & & \\
Palaemonella rotumana (Borradaile, 1898) & Lizard Is. (AU) & KR088755 & MTQ-33176 \\
\hline
\end{tabular}

0.3-0.4 $\mu \mathrm{M}$ primers, $0.15 \mathrm{mM}$ dNTP, $0.7 \mathrm{U} / \mu \mathrm{L}$ Taq polymerase, $10 \times \mathrm{PCR}$ buffer, $1.5-3 \mathrm{mM} \mathrm{MgCl}_{2}$ and distilled water.

For the COI segments, PCR products were amplified using the universal primer pairs LCO 1490/HCO 2198 (Folmer et al. 1994). The thermal cycling profile conformed to the following parameters: $2.5 \mathrm{~min}$ at $94^{\circ} \mathrm{C}$ for initial denaturing, followed by 40 cycles of $30 \mathrm{~s}$ at $90{ }^{\circ} \mathrm{C}, 1 \mathrm{~min}$ at $48{ }^{\circ} \mathrm{C}, 1 \mathrm{~min}$ at $72{ }^{\circ} \mathrm{C}$, and a final extension step at $72{ }^{\circ} \mathrm{C}$ for $10 \mathrm{~min}$. The PCR products were purified using GenElute PCR cleanup kit (Sigma, Aldrich, Germany). Sequencing reactions were performed using an ABI3730XL DNA Sequencer from Macrogen, Ins., Amsterdam. Partial segments of the COI mitochondrial gene (645 bp) were used for phylogenetic analysis and were deposited in GenBank (Table 1).

\section{Phylogenetic analysis}

Forward and reverse sequences were manipulated with Chromas v2.4.1, and multiple sequence alignment was conducted with MUSCLE (Edgar 2004) using the default settings within the software package MEGA6 (Tamura et al. 2013). Overall 12 specimens of the genus Hamodactylus were covered in the phylogenetic analyses; 6 of them were obtained from GenBank (Table 1).

The software jModelTest 2.1.6 (Darriba et al. 2012) was used to evaluate the best-fitting substitution model using the Bayesian Information Criterion. Maximum likelihood (2,000 replications) was conducted in MEGA6 and the Bayesian analysis (SD of split frequencies < 0.05) using MrBayes v3.2.3 (Ronquist et al. 2012) via the on-line CIPRES Science Gateway v3.3 (Miller et al. 2010), both analyses 
under the resultant Hasegawa-Kishino-Yano $(\mathrm{HKY}+\mathrm{I}+\mathrm{G})$ model. The palaemonid shrimp Palaemonella rotumana (Borradaile, 1898) was used as outgroup. The number of base differences per site between COI gene sequences was calculated in MEGA6.

Phylogenetic relationships among reconstructed mtDNA haplotypes were estimated using a medianjoining network (Bandelt et al. 1999) and drawn using NETWORK software (http://www.fluxusengineering.com/netwinfo.htm).

\section{Results}

\section{Systematics}

Family Palaemonidae Rafinesque, 1815

Genus Hamodactylus Holthuis, 1952

\section{Generic diagnosis (modified from Bruce 1994)}

Small sized shrimps. Rostrum compressed, with high carina, dorsal margin generally elevated, dentate, ventral margin obsolete, lateral carinae feebly developed. Carapace smooth, glabrous; inferior orbital angle distinct, orbit feebly developed, supraorbital spines present or absent, antennal and hepatic spines present, anterolateral branchiostegite not produced. Abdomen smooth, glabrous, pleura all rounded. Telson with one or two pairs of small dorsal spines and three pairs of posterior spines. Antennule normal, flagella reduced. Antenna with basicerite unarmed, scaphocerite well developed. Eye well developed, elongate, cornea oblique. Epistome unarmed. Mandible without palp, molar process reduced, styliform, with setose apex, incisor process expanded or normal, with 4-5 teeth distally; maxillula with bilobed palp, upper lacinia broad, lower lacinia slender; maxilla with simple palp, basal endite simple or bifid, coxal endite obsolete, scaphognathite well developed; first maxilliped with short, simple palp, basal endite broad, coxal endite obsolete, caridean lobe of exopod well developed, flagellum short or vestigial, epipod rounded or triangular, feebly bilobed; second maxilliped with normal endopod, dactylar segment reduced, exopod absent, coxa with rounded epipod, without podobranch; third maxilliped with ischiomeral segment fused to basis, normal or broadened, without exopod, coxa with small lateral plate, with or without arthrobranch. Fourth thoracic sternite without median process, posterior sternites broad. First pereiopod slender, chelae with fingers feebly subspatulate, cutting edges unarmed or toothed distally, with thin denticulate lamella laterally on distal part. Second pereiopods feebly developed, smaller than first pereiopods, chela with fixed finger normal, unarmed, or partially to fully reduced in size. Ambulatory pereiopods moderately robust, dactyls well developed, simple, with distinct unguis, propodi non-spinulate. Uropod with protopodite unarmed, exopod of uropod distolaterally with small or obsolete marginal tooth and movable spine more mesially.

\section{Distribution}

Widely distributed in the Indo-West Pacific region from the Red Sea to New Caledonia (e.g., Bruce 1981, 1982, 1983; Chace \& Bruce 1993; Fransen \& Rauch 2013).

\section{Ecology}

Reported in association with gorgonarians and alcyonaceans (Bruce 1970b, 1981, 1983; Bruce \& Svoboda 1983); scleractinian coral (Fransen \& Rauch 2013), from depths of 2-27.5 m (Bruce 1970b, 1983). 


\title{
Hamodactylus paraqabai sp. nov.
}

urn:1sid:zoobank.org:act:D50ED903-8CDF-4B68-BE54-8E4F2177FB2B

\author{
Figs $1-5,10 \mathrm{~B}-\mathrm{C}$
}

\section{Etymology}

The specific name paraqabai is a noun composed of the prefix para- (from Greek: besides) and the adjective -aqabai, a species name used for $H$. aqabai, a closely similar species from the Red Sea.

\section{Material examined}

\section{Holotype}

PAPUA NEW GUINEA: ovigerous \& (PoCL $1.5 \mathrm{~mm}$ ), Madang, Krangket Is., stn PR3, 05⒒3' S $145^{\circ} 49.1^{\prime}$ E, lagoon, depth 13 m, on Nephthea sp., 6 Nov. 2012, coll. Z. Duriš, fen PNG12-17 (GenBank acc. nr. KR088751) (MNHN-IU-2013-11092).

\section{Paratypes}

PAPUANEW GUINEA: 1 ovigerous 9 (PoCL $1.9 \mathrm{~mm}$ ), same data as holotype (MNHN-IU-2013-10551);

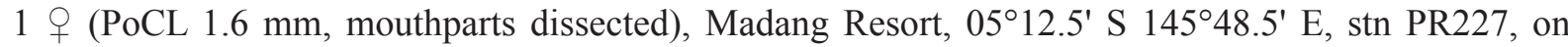
Nephthea sp., 10 Dec. 2012, coll. A.F. Berberian, leg. Z. Duriš, fen PNG12-638 (GenBank acc. nr. KR088752) (MNHN-IU-2013-11090).

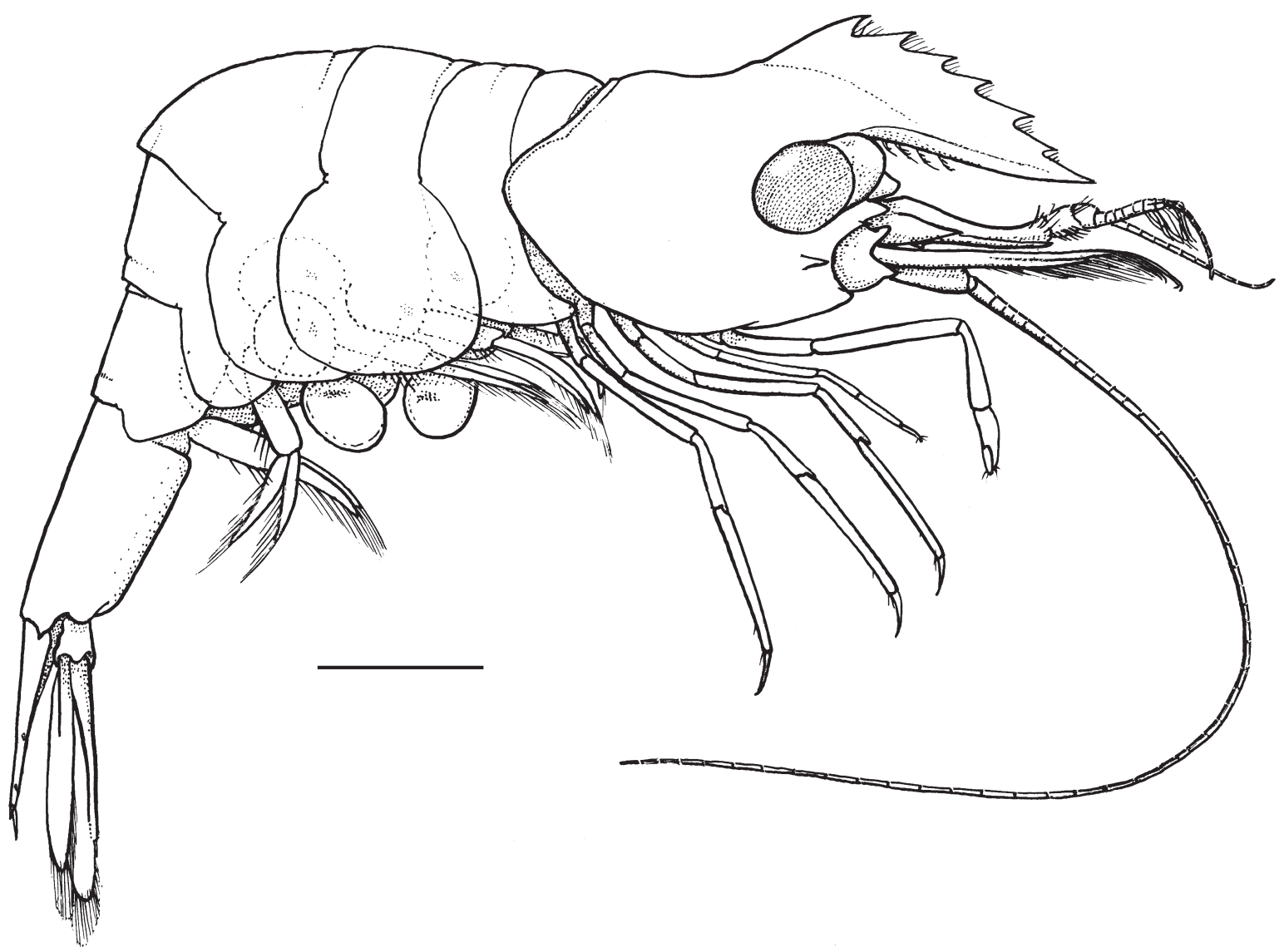

Fig. 1. Hamodactylus paraqabai sp. nov., ovigerous + , holotype (PoCL 1.5 mm; Madang, Papua New Guinea), habitus. Scale bar $=1 \mathrm{~mm}$. 


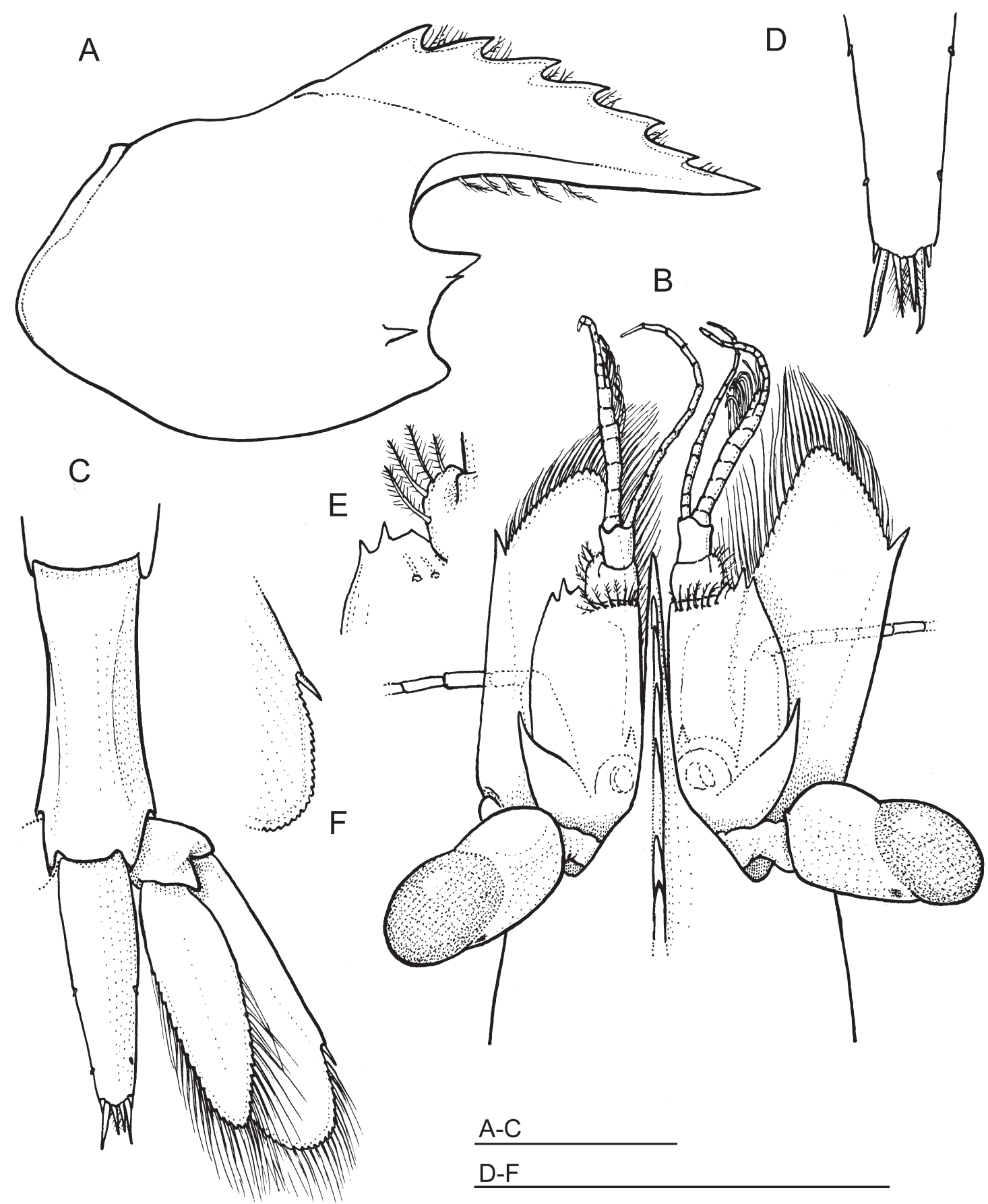

Fig. 2. Hamodactylus paraqabai sp. nov., ovigerous ${ }_{+}$, holotype (PoCL $1.5 \mathrm{~mm}$; Madang, Papua New Guinea). A. Carapace and rostrum, lateral. B. Anterior cephalothorax and appendages, dorsal. C. Sixth abdominal segment, telson and uropod, dorsal. D. Posterior part of telson, dorsal. E. Antennule, detail of distolateral angle of proximal segment and lateral border of intermediate segment. F. Distolateral angle of uropodal exopod, dorsal. Scale bars $=1 \mathrm{~mm}$. 


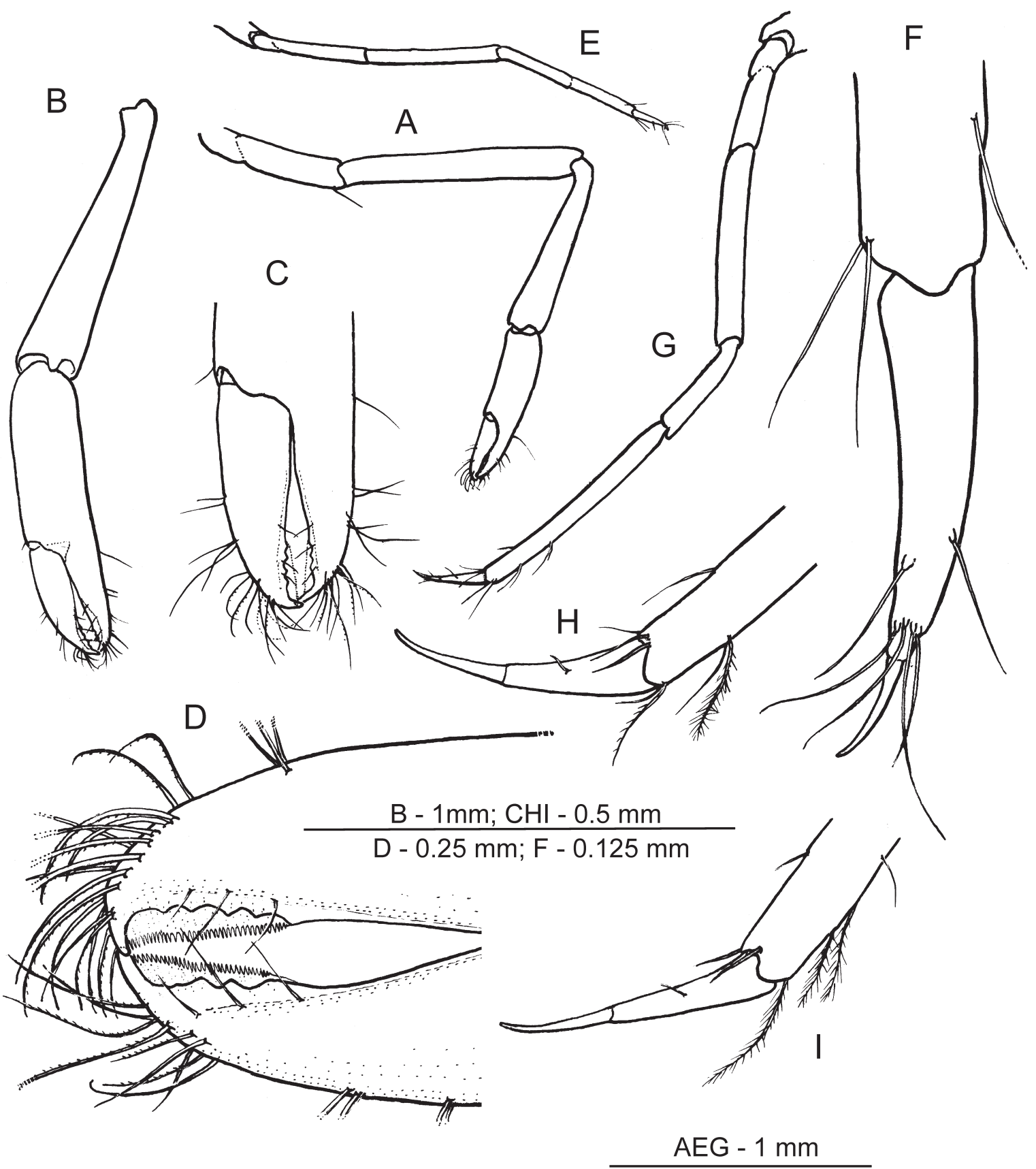

Fig. 3. Hamodactylus paraqabai sp. nov., ovigerous $q$, holotype (PoCL 1.5 mm; Madang, Papua New Guinea). A. Right first pereiopod. B. Same as previous, chela and carpus. C. Same as previous, fingers. D. Same as previous, detail of denticulations. E. Second pereiopod, lateral. F. Same as previous, dactylus and distal propodus. G. Third pereiopod. H. Same as previous, dactylus and distal propodus. I. Fifth pereiopod, dactylus and distal propodus. 


\section{Additional material}

AUSTRALIA, Great Barrier Reef, Lizard Island, from soft branchy corals (Alcyonacea), coll. \& leg. Z.

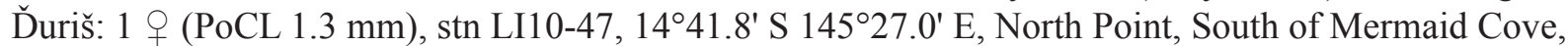
depth 9 m, on Nephthea sp., 1 Sep. 2010, fon Au10-78B (GenBank acc. nr. KR088753) (MTQ-33208);

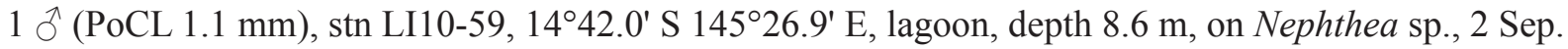
2010, fen Au10-85 (GenBank acc. nr. KR088754) (MTQ-33218).

\section{Description of holotype}

Small sized shrimp, ovigerous female; specimen complete, with all appendages (Fig. 1).

Carapace smooth. Rostrum (Fig. 2A) well developed, exceeding intermediate segment of antennular peduncle (Fig. 2B); lamina deep, lateral carina situated slightly above straight, setose, toothless ventral margin; dorsal margin convex, elevated, strongly compressed, with six subequal teeth, of which first situated above level of posterior orbital margin. Supra-orbital and epigastric spines absent. Orbit obsolescent, inferior orbital angle acutely produced in lateral view. Antennal spine small and slender, marginal, situated closely below inferior orbital angle. Hepatic spine larger and more robust than antennal, situated just behind level of posterior orbital margin and well below level of antennal spine. Antero-lateral angle moderately produced, rounded.

Abdominal segments smooth (Fig. 1). First segment pleuron highly produced anteriorly, third segment not produced posterodorsally, sixth segment twice as long as deep. Pleura all broadly rounded. Posteroventral angle of sixth segment feebly produced, postero-lateral angle feebly acute.

Telson 0.8 of length of sixth abdominal segment and 3.2 times as long as maximum width (Fig. 2C). Lateral margins convex in anterior half, posteriorly converging. Two pairs of very small marginal dorsal spines, about 0.05 of telson length, present at 0.55 and 0.8 of telson length. Posterior margin (Fig. 2D) rounded, about half of anterior width, with three pairs of spines; lateral spines short but distinctly twice as long as dorsal spines. Intermediate spines largest, about 0.2 of telson length and 1.5 times length of more slender, setulose, submedian spines.

Eyes (Fig. 2B) well developed. Cornea ellipsoid, obliquely set on stalks; stalk swollen proximally, with distinct accessory pigment spot anterodorsally.

Antennular peduncle (Fig. 2B) normal, exceeding tip of rostrum by distal segment. Basal segment broad, 2 times as long as wide, with stylocerite slender, acute, reaching almost to middle of segment; lateral border convex, anterolateral margin slightly acutely produced mesially, with 2 acute distolateral teeth (Fig. 2E); medioventral margin with tooth in front of statocyst level. Intermediate and distal segments short, together equal to 0.3 of proximal segment length. Upper flagellum biramous, with first 7 segments fused, shorter free ramus 3 -segmented and longer ramus consisting of about 10 slender segments. About 6 groups of aesthetascs present. Lower flagellum consisting of about 11-13 slender segments.

Antenna (Fig. 2B) with robust basicerite without lateral tooth. Carpocerite slender, short, reaching almost to middle of scaphocerite. Scaphocerite large, extending well beyond antennular peduncle, about 2.5 times as long as broad, with greatest width in midlength, distomedially angulated; lateral border almost straight, with acute distal tooth; lamina extending far beyond distolateral tooth.

Fourth thoracic sternite unarmed.

First pereiopod (Fig. 3A-D) slender, reaching to end of scaphocerite. Chela with palm subcylindrical, slightly bowed and compressed, about 4 times as long as wide. Fingers about 0.75 of palm length; cutting edges gaping distally, bearing series of 5 small blunt teeth at distal third on dactylus, and 3 such 
HORKÁ I. et al., Two new species of Hamodactylus (Palaemonidae)

teeth on fixed finger; very thin denticulate lamella present laterally along latter series of teeth on both fingers, tip of fingers slender, hooked. Cleaning setae present proximally on palm and on disto-ventral end of carpus, latter being subequal to chela length and 6.5 times as long as wide distally. Merus about 1.3 times as long as carpus and almost twice length of ischium. Basis and coxa normal.

Second pereiopods (Fig. 3E-F) greatly reduced, small, reaching almost to end of carpocerite, subequal and similar, resembling ambulatory pereiopod. Chela without any trace of fixed finger; dactylus resembles that of walking legs. Unguis distinct, occupying distal 0.25 of dactylus length, corpus slender, 4.2 times as long as basal width, slightly curved, without accessory spines or teeth, long setae arising from distal and subdistal part of corpus. Propodus subcylindrical, unarmed, about 6.5 times as long as wide and 2
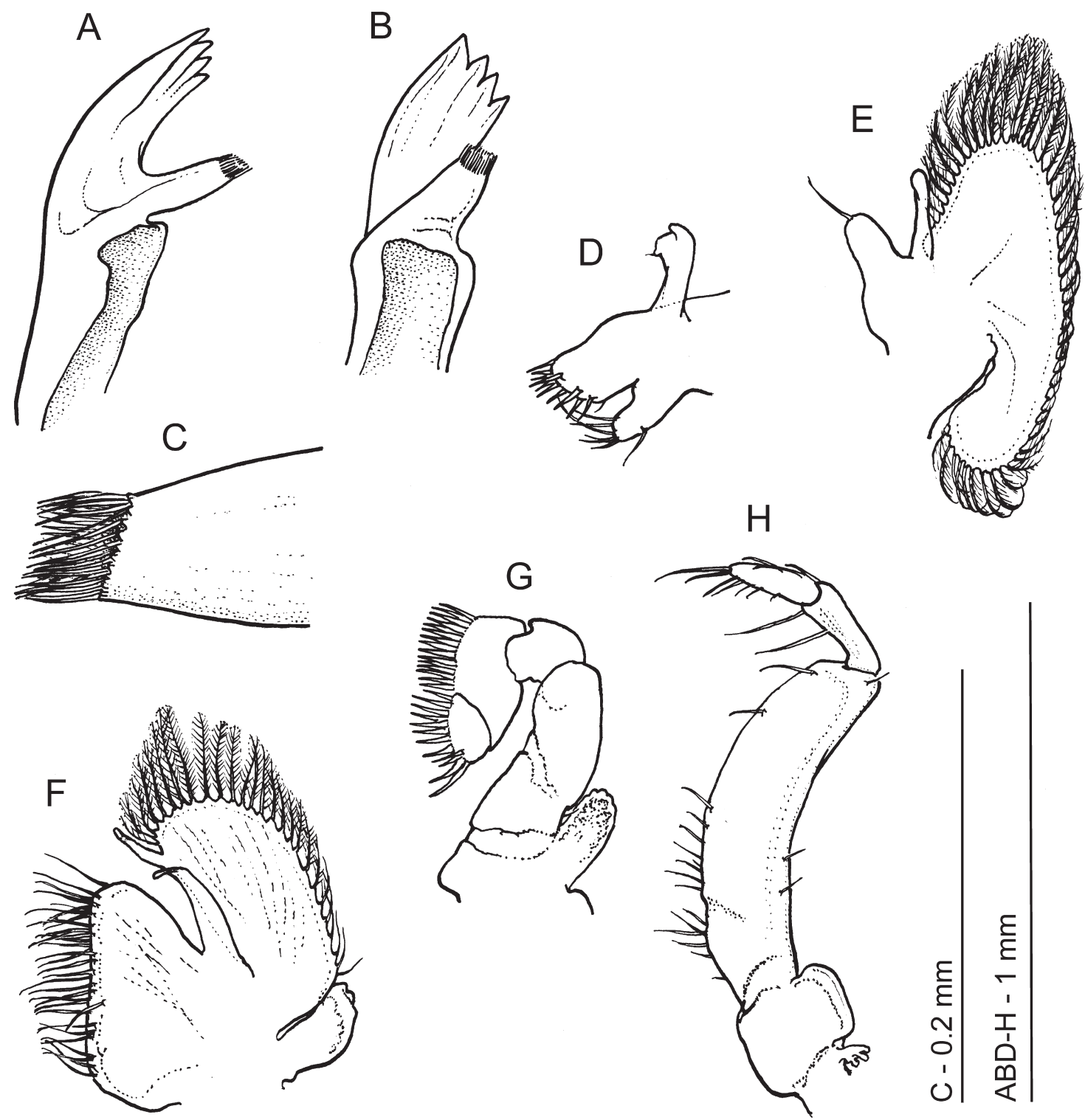

Fig. 4. Hamodactylus paraqabai sp. nov., +, paratype (PoCL $1.6 \mathrm{~mm}$, Madang, Papua New Guinea, MNHN-IU-2013-11090), mouthparts. A. Mandible. B. Same as previous, turned. C. Same as previous, molar process. D. Maxillula. E. Maxilla. F. First maxilliped. G. Second maxilliped. H. Third maxilliped. 
times length of dactylus; dactylus unarmed. Carpus, merus and ischium unarmed, lengths in ratio of 1.2, 1.0 and 1.6 times length of propodus. Basis and coxa normal.

Ambulatory pereiopods slender, distinctly longer and more robust than second pereiopods. Third pereiopod (Fig. 3G) exceeds tip of scaphocerite by dactylus. Dactylus (Fig. 3H) slender, uniformly tapering, unarmed and with a distinct unguis on distal 0.45 of length, total length about 5 times width near base. Propodus about 12 times as long as wide, 3 times length of dactyl, and devoid of spines. Carpus, merus and ischium 0.5, 0.8 and 0.5 of propodus length, unarmed. Fourth and fifth pereiopods similar, dactylus of fifth pereiopod (Fig. 3I) slightly more slender and straighter than that of third leg.

Uropods (Fig. 2C) slender, extending well beyond tip of telson. Protopodite unarmed laterally. Exopod about 3 times as long as wide, extending well beyond endopod, with lateral border almost straight, entire, terminating in small mobile spine (Fig. 2F). Endopod 3.3 times as long as wide.

Mouthparts (Fig. 4; dissected from female paratype MNHN-IU-2013-11090). Mandible (Fig. 4A-C) with reduced cylindrical molar process bearing a few brushes of setae distally (Fig. 4C). Incisor process slightly expanded distally, with four large teeth on truncated tip, of which lateral most enlarged. Palp absent.

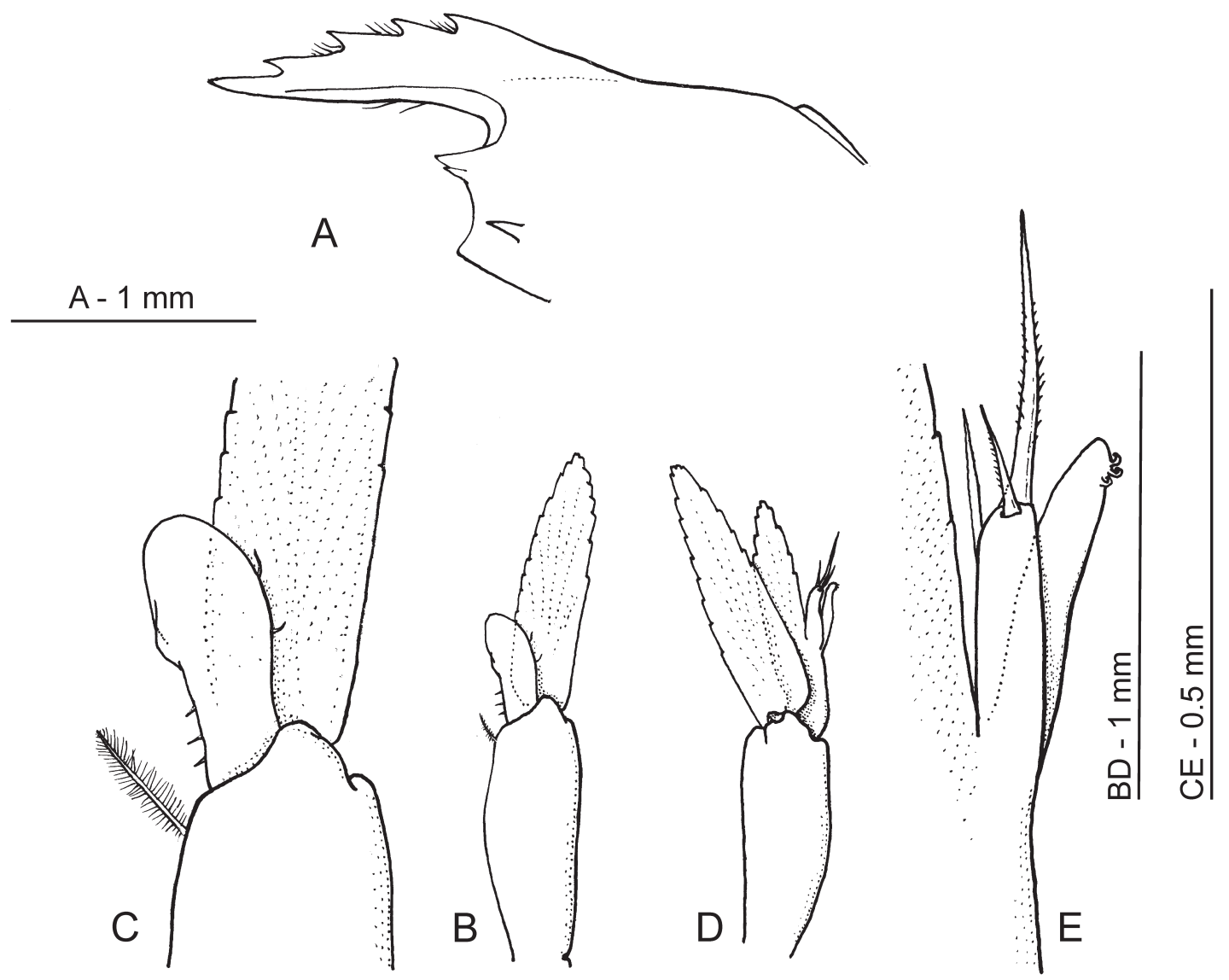

Fig. 5. Hamodactylus paraqabai sp. nov., ô (PoCL $1.1 \mathrm{~mm}$, Lizard Is., Australia, MTQ-33218). A. Carapace and rostrum, lateral. B. First pleopod. C. Same as previous, endopod. D. Second pleopod. E. Same as previous, appendices interna and masculina. 
Maxillula (Fig. 4D) with slender, feebly bilobed palp, lower lobe bearing a small seta distally. Upper lacinia short and stout, truncate distally, with about 10 robust spines distally. Lower lacinia more slender, with group of long setae on truncate tip.

Maxilla (Fig. 4E) with distally tapering, non-setose palp. Basal endite simple, short, stout and blunt, with simple seta distally. Coxal endite obsolete, medial region slightly convex. Scaphognathite normal, widest centrally, about 2 times as long as broad, with more slender posterior lobe. Marginal plumose setae well developed.

First maxilliped (Fig. 4F) with slender, tapering, non-setose palp. Basal region broad and round, not distinctly separated from coxal region. Median margin straight, sparsely provided with slender setulose setae. Caridean lobe of exopod distinct, with plumose marginal setae; flagellum greatly reduced, devoid of setae, slightly overreaching caridean lobe. Epipod small, somewhat elongate, rounded distally.

Second maxilliped (Fig. 4G) with small dactylar segment, about 1.6 times as long as wide, convex medially, bearing row of stout, serrulate spines. Propodal segment large, twice as long as dactylar segment, twice as long as wide, with subrectangular distomedial angle. Medial margin broadly convex, with row of coarsely serrulate setae. Carpus short. Merus partly fused to ischium, ischium partly fused to basis, basis without exopod; combined segment stout, about twice as long as wide. Coxa produced medially, with small, suboval epipod laterally.

Third maxilliped (Fig. 4H) with broad antepenultimate segment, about 4 times as long as wide. Basis completely fused with ischiomerus, junction indicated medially by small knob; median margin sparsely provided with serrulate setae over proximal two thirds. Penultimate segment slender, about 3 times as long as wide, 0.33 of length of antepenultimate segment and with 2 slender, serrulate setae on medial border. Terminal segment 3 times as long as wide, slightly shorter than penultimate segment, with groups of serrulate setae medially and slender terminal setae. Exopod absent. Coxa not produced medially, with broadly rounded lateral lobe and small reduced arthrobranch laterally.

\section{Other specimens}

Females similar to holotype. Dorsal rostrum teeth varying from 4 (smaller specimen, PoCL $1.2 \mathrm{~mm}$, damaged, lost) to 5, lamina shallower in smallest specimens, first pereiopod fingers with 3-4 distal cutting teeth. Single male specimen available (Fig. 5) comparatively smaller and more slender than adult females; rostrum (Fig. 5A) more shallow, bearing 4 dorsal teeth; first male pleopod (Fig. 5B-C) with endopod almost half length of exopod, enlarged distally, with apex rounded, with 3 short simple setae proximally on medial border and 2 short setae more distally on lateral border; second pleopod (Fig. 5D-E) with endopod slightly shorter than exopod, with appendix masculina about as long as appendix interna, with two unequal distal serrulate setae and one simple seta subdistally on lateral margin.

Measurements (PoCL, RL; mm)

Ovigerous females: 1.9, 1.8; holotype: 1.5, 1.5. Other females 1.3-1.6, 1.2-1.4 (in female of PoCL 1.6, TL $9.5 \mathrm{~mm}$ ). Male: 1.1, 1.0. Eggs (with eye spots): $0.54-0.65 \times 0.40-0.45$.

\section{Colouration (Fig. 10B-C)}

Males largely transparent, with diffuse yellow and white speckles, more dense on cephalothorax. Adult females more heavily coloured. Body generally transparent, faintly speckled with yellow and white colour, with yellow dots on base of the rostrum and on eyestalks, yellow colour more condensed to transverse bands on sides of each basis of antennae, two bands on carapace, and one wide band on each of $1^{\text {st }}$ to $5^{\text {th }}$ abdominal segments, all interspaced by faint white dots. Whitish path transversely on the tailfan articulations to the last abdominal segment. Anterior rostrum, antennal flagella, pereiopods, the 
sixth abdominal segment, and tailfan, predominantly transparent. One female from Papua New Guinea reddish coloured instead of yellow.

\section{Host}

Associated with branching soft corals of the genus Nephthea sp. (Fig. 10C) of the family Nephtheidae (Octocorallia: Alcyonacea).

\section{Distribution}

Up to date known from the Madang Lagoon, Papua New Guinea, and the Great Barrier Reef, Australia.

\section{Remarks}

See the Discussion.

Hamodactylus pseudaqabai sp. nov. urn:1sid:zoobank.org:act:5306FF2F-64E9-47A5-8554-393952257DEF

Figs 6-9, 10D

Hamodactylus aqabai - Fransen 2012: 102. — Fransen \& Rauch 2013: 287 (Tab. 1), 288 (comparative material).

non H. aqabai - Bruce \& Svoboda 1983: 26, figs 10-14.

\section{Etymology}

The specific name pseudaqabai is a noun combined from the prefix pseudo-(Greek: false) and the suffix -aqabai, the species name used for H. aqabai, a very similar species from the Red Sea.

\section{Material examined}

Holotype

INDONESIA: ovigerous 우 (PoCL $2.0 \mathrm{~mm})$, North Sulawesi, Lembeh Strait, Kelapadua, $1^{\circ} 26.1^{\prime} \mathrm{N}$ 125⒓6' E, stn LEM.12, depth 4 m, on nephtheid Alcyonacea, 4 Feb. 2012, coll. C.H.J.M. Fransen (GenBank acc. nr. KT598272) (RMNH.CRUS.D.57195).

\section{Allotype}

INDONESIA: 1 § (PoCL $1.4 \mathrm{~mm}$ ), same data as holotype (RMNH.CRUS.D.57007).

\section{Paratypes}

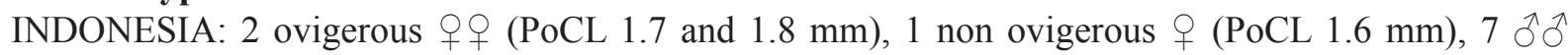
(PoCL 0.9-1.1 mm), 7 juveniles (PoCL 0.7-0.9 mm), Moluccas, Ambon, W side of Pombo Island, stn RBE.16, depth 10 m, diving, from nephtheid Alcyonacea (host preserved), 15-17 Nov. 1990, coll. C.H.J.M. Fransen (RMNH.CRUS.D.48243); 1 o (PoCL $1.7 \mathrm{~mm}$ ), SW Sulawesi, Spermonde Archipelago, S side, depth 10 m, scuba diving, on purple Nephthea, 26 Sep. 1994, leg. C.H.J.M. Fransen (RMNH.CRUS.D.46369); 1 non ovigerous 9 (PoCL $1.4 \mathrm{~mm}$ ), Moluccas, Ambon, Outer bay, N coast

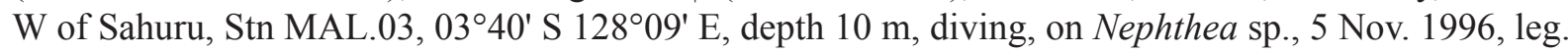
C.H.J.M. Fransen (RMNH.CRUS.D.47481).

MALAYSIA: 1 ovigerous + (PoCL $2.2 \mathrm{~mm}$ ), Ligitan reef N2, Semporna area, Sabah, stn SEM.09b, 04 $4^{\circ} 15.0^{\prime} \mathrm{N} 118^{\circ} 37.9^{\prime} \mathrm{E}$, depth $10 \mathrm{~m}$, on nephtheid Alcyonacea, 1 Dec. 2010, coll. Nina Ho (GenBank acc. nr. KC633175) (RMNH.CRUS.D.53969). 


\section{Description of holotype (ovigerous + )}

Small sized shrimp with slender pereiopods (Fig. 6).

Carapace smooth. Rostrum well developed, almost reaching distal margin of antennular peduncle (Fig. 7A-C), lamina deep, lateral carina situated near to slightly convex, setose, toothless ventral margin; dorsal margin convex, elevated, strongly compressed, with 6 subequal teeth, with first one situated above level of posterior margin of orbit. Supra-orbital and epigastric spines absent. Antennal spine small and slender, marginal, situated closely below inferior orbital angle. Hepatic spine larger and more robust than antennal spine, situated just behind level of posterior orbital margin and well below level of antennal spine. Orbit obsolescent, inferior orbital angle well developed, acutely produced in lateral view. Antero-lateral angle of carapace moderately produced.

Abdominal segments smooth (Fig. 6), with all pleurae broadly rounded posteroventrally. First segment pleuron highly produced anteriorly, third segment not produced posterodorsally, fifth segment dorsal length about half length of sixth segment; latter twice as long as deep, with posteroventral angle feebly produced and postero-lateral angle subtriangular, pointed.

Telson (Fig. 7D-E) 0.8 times as long as sixth abdominal segment and 3.2 times as long as maximum width; lateral margins converge posteriorly, feebly over anterior half and more strongly over posterior

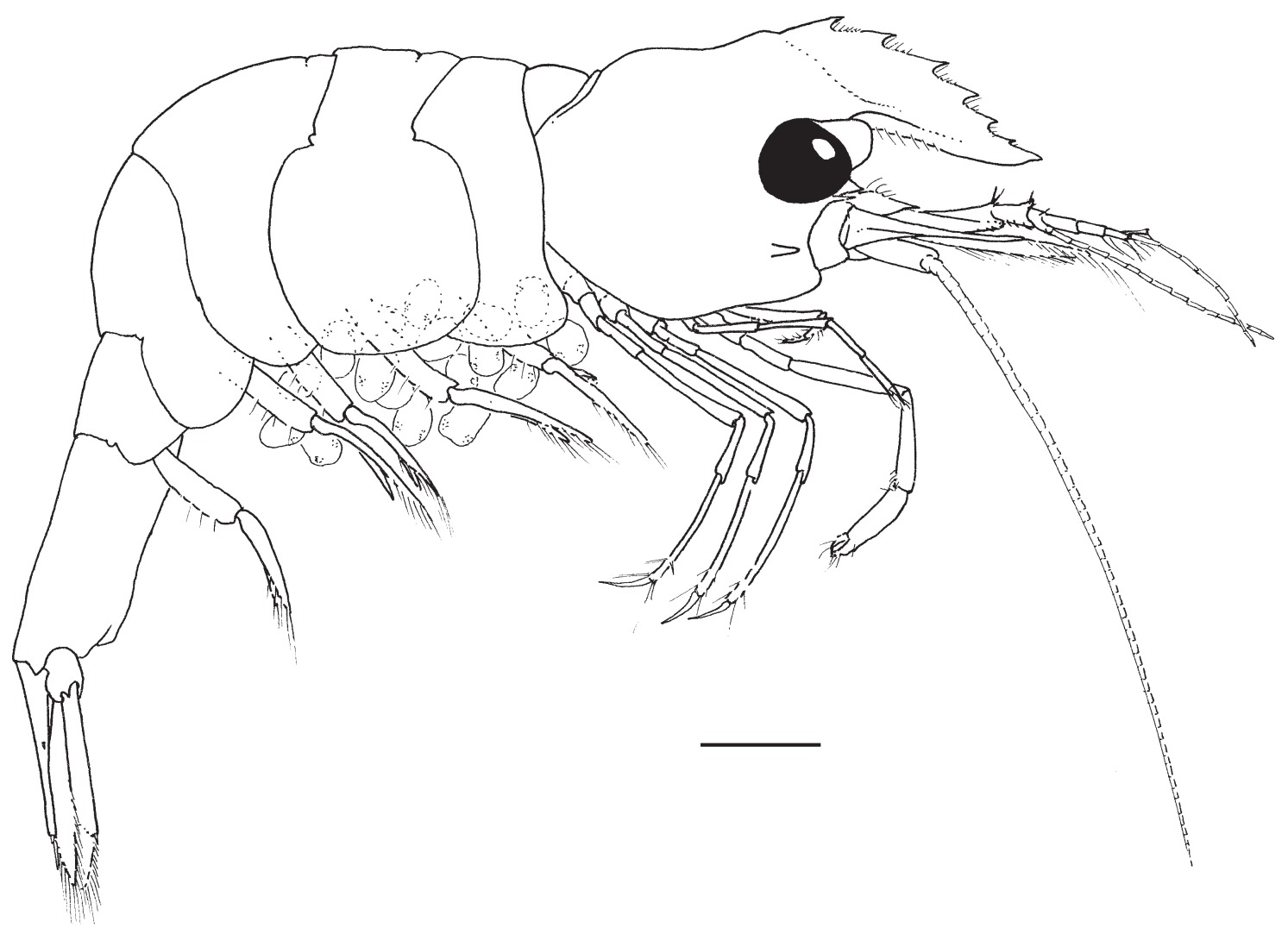

Fig. 6. Hamodactylus pseudaqabai sp. nov., ovigerous + , holotype (PoCL $2.0 \mathrm{~mm}$, N. Sulawesi, RMNH. CRUS.D.57195), habitus, lateral view. Scale bar $=1 \mathrm{~mm}$. 

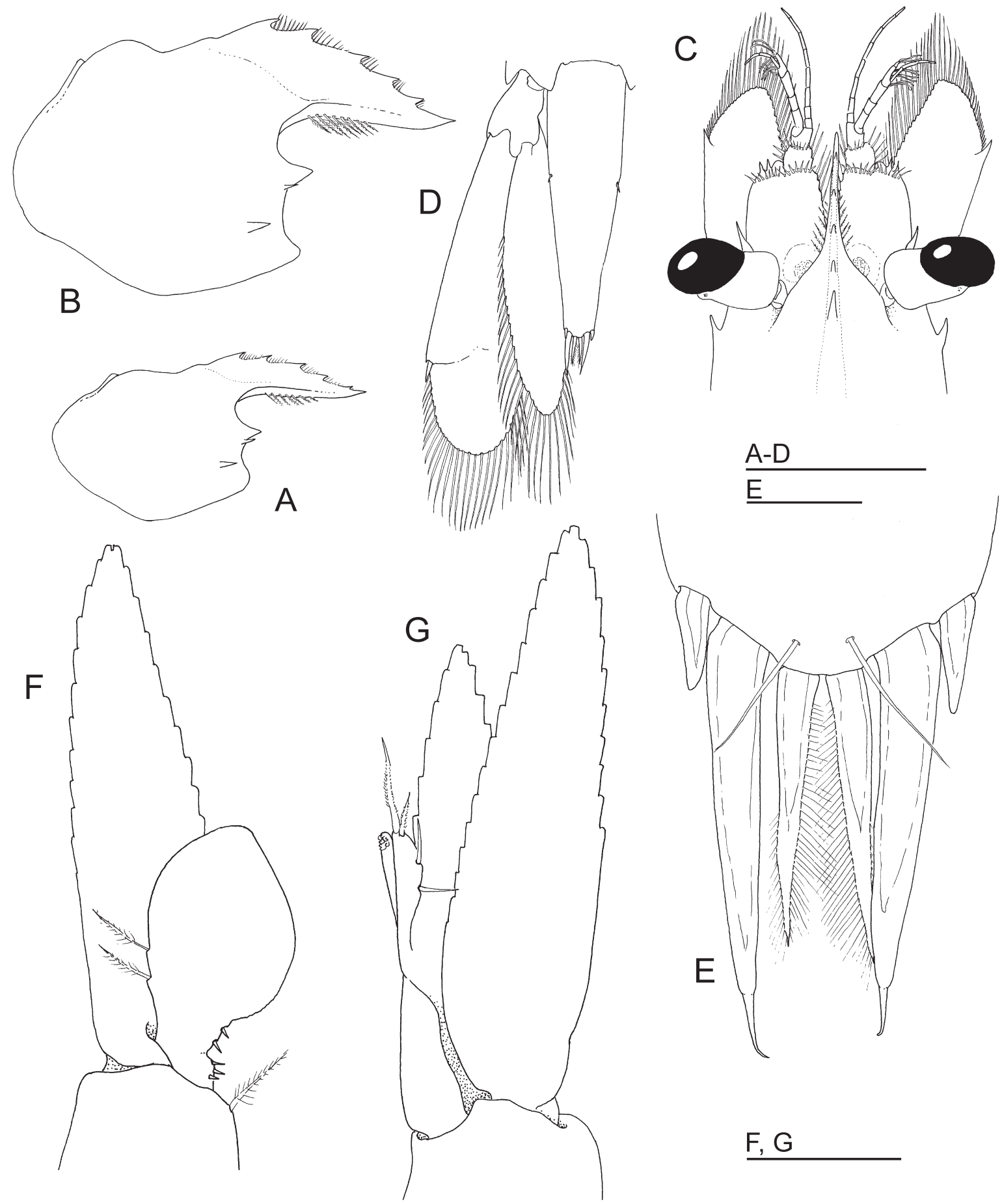

Fig. 7. Hamodactylus pseudaqabai sp. nov., Ô, allotype (PoCL $1.4 \mathrm{~mm}$, N. Sulawesi, RMNH. CRUS.D.57007) (A, F-G), and ovigerous 9 (PoCL $2.2 \mathrm{~mm}$, Sabah, Malaysia, RMNH.CRUS.D.53969) (B-E). A-B. Carapace and rostrum, lateral view. C. Anterior carapace and appendages, dorsal view. D. Tail fan, dorsal view. E. Same as previous, tip of telson. F. First male pleopod. G. Second male pleopod. Scale bars: $\mathrm{A}-\mathrm{C}=2 \mathrm{~mm} ; \mathrm{D}=1.25 \mathrm{~mm} ; \mathrm{E}=0.25 \mathrm{~mm} ; \mathrm{F}-\mathrm{G}=1 \mathrm{~mm}$. 
half. One pair of very small marginal dorsal spines present at about 0.42 of telson length. Posterior margin feebly angular, about one third of anterior width, with three pairs of spines. Lateral spines short, but distinctly longer than dorsal spines. Intermediate spines well developed, 0.15 of telson length and 1.5 times length of more slender submedian spines, which are finely plumose.

Eyes (Fig. 7C) well developed. Cornea globular, obliquely set on proximally swollen stalks, with distinct accessory pigment spot posteriorly.

Antennular peduncle (Fig. 7C) exceeding tip of rostrum by $1 / 3$ length of distal segment. Proximal segment broad, 1.6 times as long as wide. Stylocerite slender and acute, reaching almost to middle

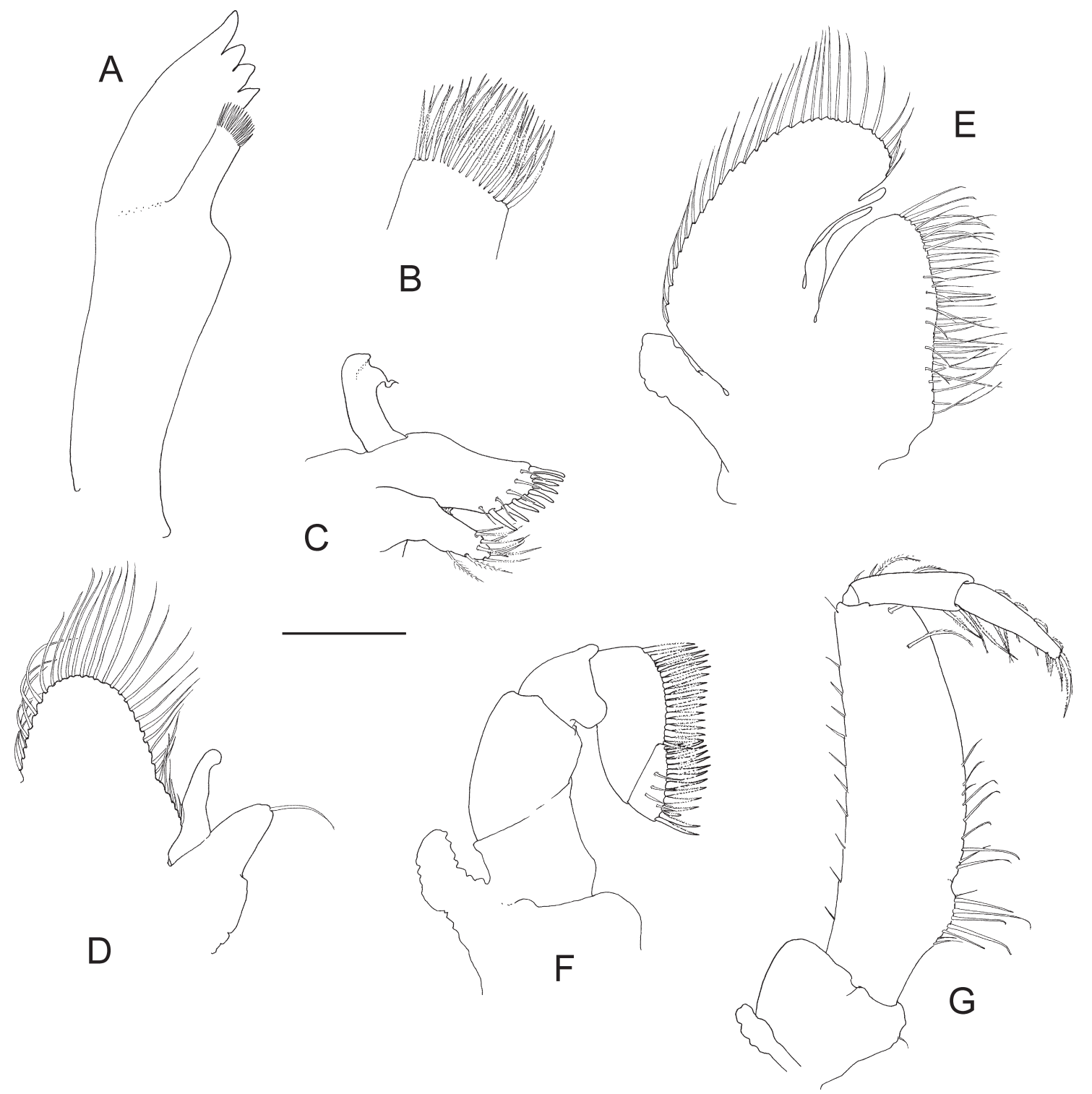

Fig. 8. Hamodactylus pseudaqabai sp. nov., ovigerous ${ }^{\text {, }}$, paratype (PoCL $2.2 \mathrm{~mm}$, Sabah, Malaysia, RMNH.CRUS.D.53969), mouthparts. A. Left mandible, ventral view. B. Same as previous, detail of molar process. C. Right maxillula, ventral view. D. Right maxilla, ventral view, posterior lobe of scaphognathite lost in dissection. E. Right first maxilliped, ventral view. F. Right second maxilliped, ventral view. G. Right third maxilliped, ventral view. Scale bars: $A, C-G=1 \mathrm{~mm} ; B=0.25 \mathrm{~mm}$. 
of segment. Lateral border feebly convex and anterolateral margin slightly produced, bearing 4 acute teeth and numerous setae. Medial ventral margin with tooth at about third of length. Statocyst normally developed and contains a granular statolith. Intermediate and distal segments short, together equal to 0.34 of proximal segment length. Upper flagellum biramous, with first three segments of each ramus fused. Shorter free ramus indistinctly segmented and longer ramus consists of about 9 slender segments, five groups of aesthetascs present, lower flagellum slightly longer than upper flagellum, with about 13 segments.

Antenna (Fig. 7C) with robust basicerite, without lateral tooth. Ischiocerite and merocerite normal. Carpocerite slender, reaching to middle of scaphocerite. Scaphocerite large and broad, lamella extends well beyond antennular peduncle. Lateral border almost straight and ends in an acute distal tooth. Lamella extends far beyond tooth, feebly angulated distomedially, about 2.2 times as long as broad, with greatest width at about one third of its length.

Fourth thoracic sternite unarmed.

Mouthparts (Fig. 8; dissected from Malayan ovigerous female paratype). Mandible (Fig. 8A-B) rather feeble, with cylindrical molar process (Fig. 8B) bearing a few brushes of setae distally. Incisor process of normal size, with four teeth distally, of which lateral most enlarged. Mandible without palp.
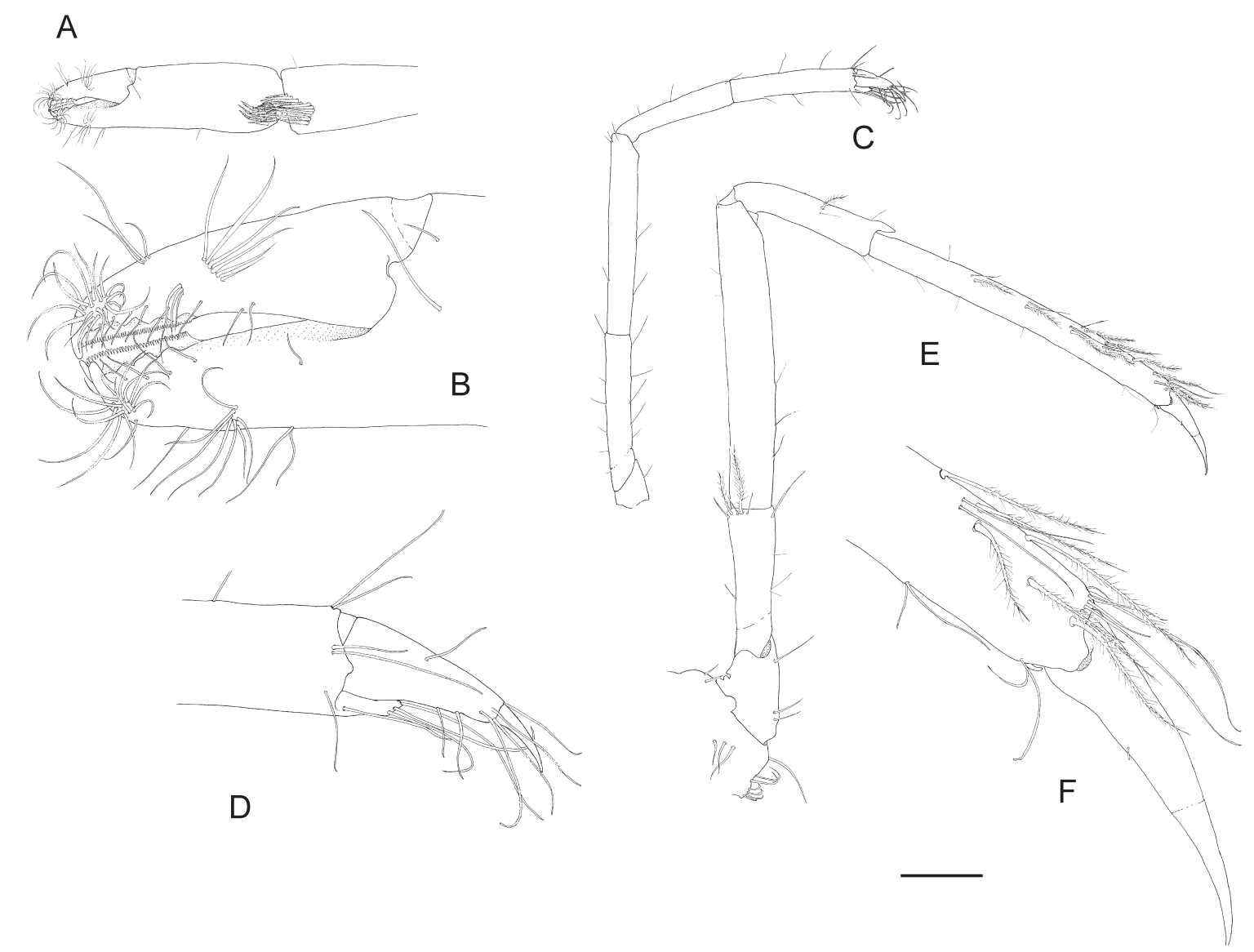

Fig. 9. Hamodactylus pseudaqabai sp. nov., ovigerous + , paratype (PoCL $2.2 \mathrm{~mm}$, Sabah, Malaysia, RMNH.CRUS.D.53969). A. Chela of left first pereiopod. B. Same as previous, detail of fingers. C. Right second pereiopod. D. Same as previous, detail of chela. E. Right third pereiopod. F. Same as previous, dactylus and distal part of propodus. Scale bars: A, C, E = $1 \mathrm{~mm}$; B, D, F = $0.25 \mathrm{~mm}$. 
Maxillula (Fig. 8C) with slender, feebly bilobed palp, lower lobe bearing small seta distally. Upper lacinia rather short and stout, with single row of robust simple spines and few spinose setae distally. Lower lacinia slender, with several slender serrulate setae distally.

Maxilla (Fig. 8D) with tapering, non-setose palp. Basal endite simple, short, stout and blunt, with simple seta distally. Coxal endite obsolete, medial region slightly convex. Scaphognathite normal, posterior lobe lost in dissection. Marginal plumose setae well developed.

First maxilliped (Fig. 8E) with, slender, tapering, non-setose palp. Basal region broad and round, not distinctly separated from coxal region. Median margin sparsely provided with slender, setulose setae.
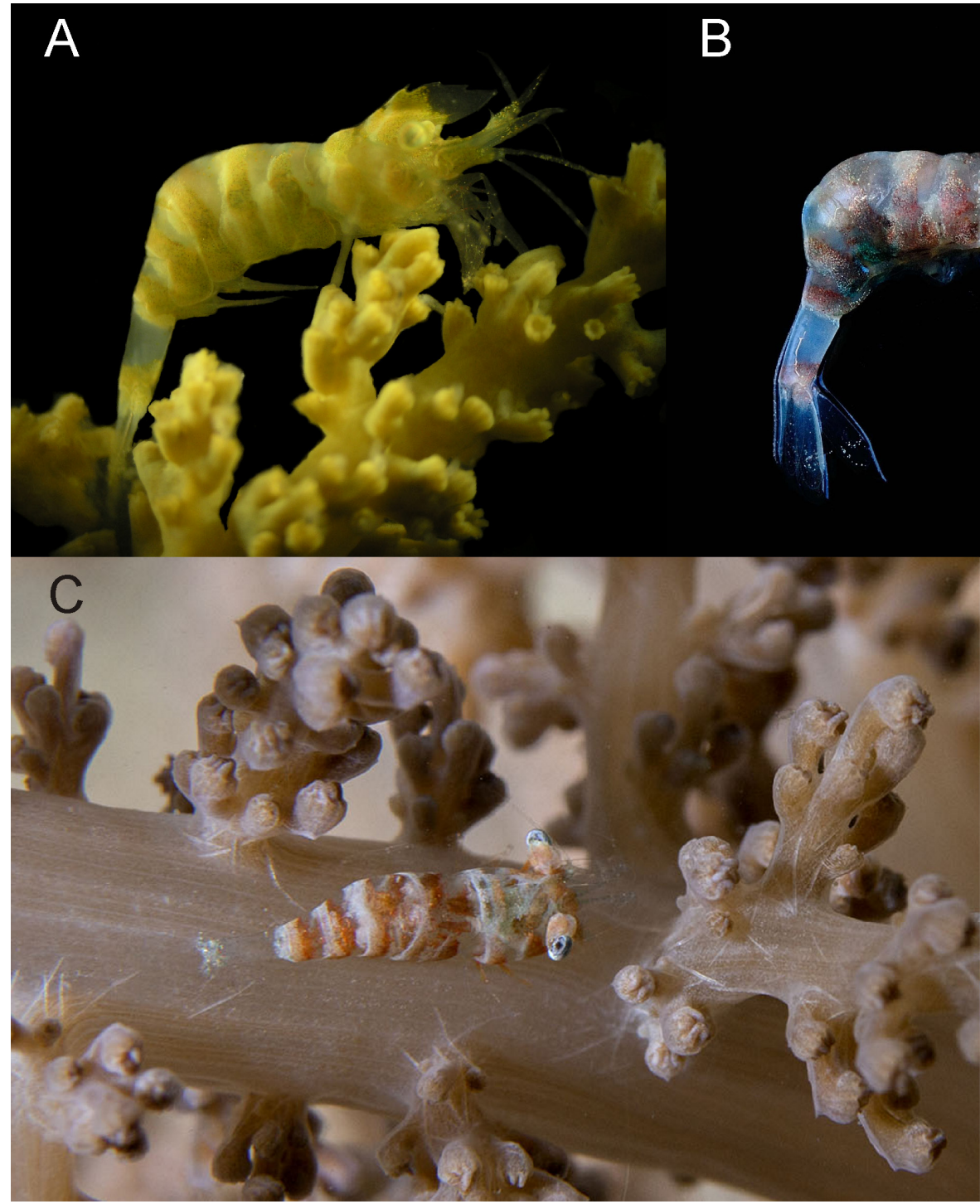

\section{B}

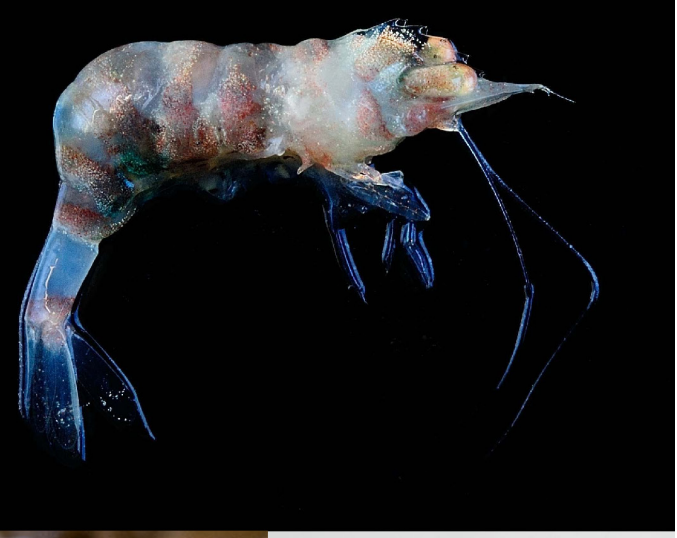

$\mathrm{D}$

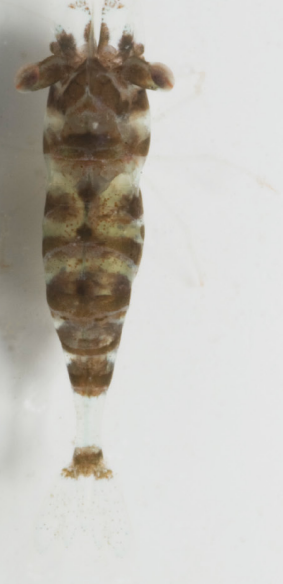

Fig. 10. Colour pattern of three relatives of the genus Hamodactylus. - A. H. aqabai Bruce \& Svoboda, 1983, ovigerous + (UO Aq09-55) on alcyonacean coral Nephthea sp., Aqaba, Red Sea. B-C. H. paraqabai sp. nov., ovigerous $\circ 9$, Madang, Papua New Guinea, on Nephthea sp. B. Holotype (MNHN-IU-2013-11092). C. Paratype (MNHN-IU-2013-11090). - D. H. pseudaqabai sp. nov., ovigerous + , holotype, N. Sulawesi, Indonesia (RMNH.CRUS.D.57195). Photos: Z. Ďuriš (A), T.Y. Chan (B), A.F. Berberian (C), C.H.J.M. Fransen (D). 
Caridean lobe distinct, with coarsely setulose, plumose marginal setae. Flagellum of exopod greatly reduced, devoid of setae. Epipod small, rounded.

Second maxilliped (Fig. 8F) with small triangular dactylar segment, about 1.6 times as long as wide, convex medially, bearing row of stout, biserrulate spines. Propodal segment large, twice as long as dactylar segment, twice as long as wide, with subrectangular distomedial angle; medial margin almost straight, with row of coarsely serrulate setae. Carpus short. Merus partly fused to ischium; ischium partly fused to basis; basis without exopod. Coxa not produced medially, with small, suboval epipod laterally.

Third maxilliped (Fig. 8G) with broad antepenultimate segment, about three times as long as proximal width. Basis completely fused with ischiomerus, junction indicated medially by small knob. Median margin sparsely provided with simple setae over proximal two thirds. A row of five long setulose setae present distally, submarginally. Penultimate segment slender, 2.9 times as long as wide, 0.36 of length of antepenultimate segment and with few slender, setulose setae distally on medial border. Terminal segment five times as long as wide, 1.1 times length of penultimate segment, with few groups of short, serrulate setae medially and slender, simple terminal setae. Exopod absent. Coxa feebly produced medially, with rounded epipod laterally. Multilamellar arthrobranch present laterally.

First pereiopod (Fig. 9A-B) slender, reaching to end of scaphocerite. Chela with palm subcylindrical, slightly bowed and compressed, about 2.3 times as long as wide. Fingers short, 0.33 of palm length, feebly subspatulate. Cutting edges gape proximally, very thin denticulate lamella laterally in distal third, with series of 4 blunt teeth medially. Tip of dactylus with distinct unguis, smaller spine present laterally. Cleaning setae present proximally on palm and on distoventral end of carpus, latter 1.2 times as long as chela, 5.0 times as long as wide and moderately wider distally. Merus about 1.2 times as long as carpus and twice length of ischium. Basis normal. Coxa with very small, medial setose process.

Second pereiopods (Fig. 9C-D) greatly reduced, equal and similar, extending slightly beyond carpocerite with fingers. Chela with strongly reduced fixed finger, about third length of corpus of dactylus, distally acute, with several long setae. Dactylus resembles that of an ambulatory pereiopod. Unguis distinct and corpus without accessory spines or teeth. Setae arise from anterior, distoventral and extreme distolateral aspects of corpus, which is about 2.3 times as long as wide and 2.3 times as long as unguis. Propodus subcylindrical, about 5.4 times as long as wide centrally and 2.3 times length of dactylus. Propodus without spines. Carpus, merus and ischium unarmed, lengths in ratio of 0.9, 1.6 and 1.1 times length of propodus. Basis and coxa normal.

Ambulatory pereiopods slender, distinctly more robust than second pereiopods. Third pereiopod (Fig. 9E-F) not exceeding scaphocerite. Dactylus slender, uniformly tapering, unarmed and with indistinct unguis. Total length about five times width near base. Propodus about twelve times as long as wide, 4.0 times length of dactylus, devoid of spines except for blunt, short ventrodistal spine, with series of plumose setae dorsolaterally. Carpus, merus and ischium $0.43,0.92$ and 0.45 of propodus length, unarmed. Fourth and fifth pereiopods similar to third.

Pleopods well developed. Marginal plumose setae of exopod and endopod coarsely serrulate.

Uropods (Fig. 7D) slender and extend well beyond tip of telson (Fig. 7E). Protopodite unarmed laterally. Exopod about 3.6 times as long as wide, extends well beyond endopod, which is 3.6 times as long as wide; with lateral border almost straight, entire, terminating in small mobile spine (Fig. 7D).

About 30 eggs of ca. $0.5 \mathrm{~mm}$ in length present under abdomen. 
HORKÁ I. et al., Two new species of Hamodactylus (Palaemonidae)

\section{Male allotype}

First pleopod (Fig. 7F) with endopod almost half length of exopod, broadly lobate with two long plumose setae lateroproximally and five short simple setae medioproximally. Second pleopod (Fig. 7G) with endopod slightly shorter than exopod, with appendix masculina about as long as appendix interna, with two distal serrulate setae and two simple setae along lateral margin.

\section{Measurements (mm)}

PoCL of ovigerous females 1.7-2.0; of non-ovigerous female 1.6; of males 0.9-1.7.

\section{Colouration}

Adult females (Fig. 10D) with semi-translucent body covered by distinct transverse bands - two on carapace and one on each of $1^{\text {st }}$ to $6^{\text {th }}$ abdominal segment; first carapacial band running dorsally from base of rostrum obliquely to sides, forming wide "V-shaped" figure on anterior dorsum; first abdominal band diffused dorsally, but compact on sides, widening ventrally; $2^{\text {nd }}$ segment with additional large spot anteriorly on sides; $6^{\text {th }}$ abdominal segment transparent except for narrow brown band posteriorly; transparent interspaces of body irregularly speckled brown. Tail fan transparent but with widely-spaced dark punctuation, with irregular, partly diffused, anterior brown portion. Eyes and bases of antennae brown, distal antennular peduncle brown speckled. Pereiopods and antennal flagella semi-translucent, whitish.

\section{Host}

Associated with soft corals of the family Nephtheidae (Octocorallia: Alcyonacea).

\section{Distribution}

Known from northeastern and southwestern Sulawesi and Ambon in Indonesia and from Sabah, Malaysia.

\section{Remarks}

There is some variation in morphological characters related with the size of the specimens examined. The smallest specimens have only 2 teeth on the dorsal side of the rostrum, whereas the largest specimens can have 6 teeth. The number of teeth along the distolateral margin of the first segment of the antennular peduncle also varies with size to some extent; the smallest specimen only has one tooth, while the larger ones can have 4 teeth. The number of fused segments of the upper antennular flagellum increases with size, up to about 5 segments. It was noted that in the larger males, the number of series of aesthetascs on the upper antennular flagellum was much higher than in juveniles and females, reaching about 11. Also the number of segments of the longer free ramus of the upper antennular flagellum was much larger, as is its length. The same holds for the lower antennular flagellum.

In the small specimens, the distal denticulate lamina with the blunt teeth medially on the cutting edge of the chela of the first pereiopod is absent. Pleopods are longer in males than in females.

Most examined specimens of the type series are consistent in the presence of only one pair of the dorsal telson spines, while the distal pair, clearly present in most congeners, is missing in all specimens of H. pseudaqabai sp. nov. In the larger specimens the remaining pair of small spines is situated in the middle of the telson (Figs 6, 7D). In the smaller specimens of RMNH.CRUS.D.48243 this pair of spines is also missing and the telson is thus fully devoid of the dorsal spines.

\section{Molecular analysis}

The obtained phylogenetic tree resolved by Maximum Likelihood based on COI sequence data (Fig. 11A) indicates, with high basal support of both the ML and BI methods, two genetic lineages among described species of the genus Hamodactylus. The first one is composed of H. boschmai together 
with H. macrophthalmus (their mutual division is well supported basally by the BI method) and the second one contains all the remaining species. In the second clade, H. noumeae occupies the basal position, subsequently followed by $H$. aqabai. The latter species is a sister taxon to the terminal couple of new species, $H$. paraqabai sp. nov. and H. pseudaqabai sp. nov. The genetic divergence of $H$. aqabai in relation to the pair of new species reaches $14-15 \%$. While the genetic distance between those new species is comparatively low (3-4\%), their subdivision is well supported basally.

The median-joining network (Fig. 11B) reveals two well separated groups of nodes for haplotypes respective to the two new species (colour circles) described in this paper, and hypothesised haplotypes (small black circles). The links connecting the nodes indicate the number of character differences. The shortest interspecific link from one species to another represents 15 mutation events for the COI gene. The intraspecific haplotype network covers 7 mutation events for two analysed $H$. pseudaqabai sp. nov., but up to 11 mutations between 4 specimens of $H$. paraqabai sp. nov.; just one mutation is indicated for the Australian specimens of $H$. paraqabai sp. nov., but 10 mutations for their two conspecifics from Papua New Guinea (or 1-7, if the hypothesised haplotypes are included).

\section{Discussion}

The genus Hamodactylus currently contains six species, including the two new ones described here. The genus is unique among symbiotic palaemonid shrimps in the strong reduction in size of the second pereiopods, up to a small and slender appendage similar to an ambulatory leg, while those are generally well developed, larger and more robust, sometimes highly modified, in other symbiotic palaemonids. Other remarkable characters are more or less widely distributed among often unrelated genera. The

A

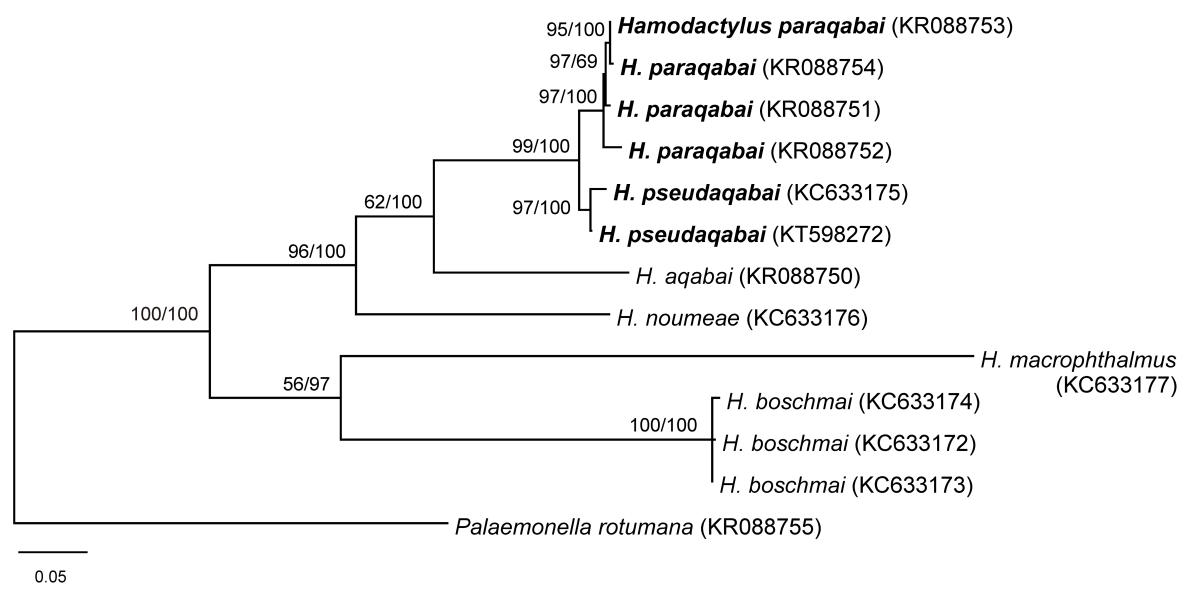

B

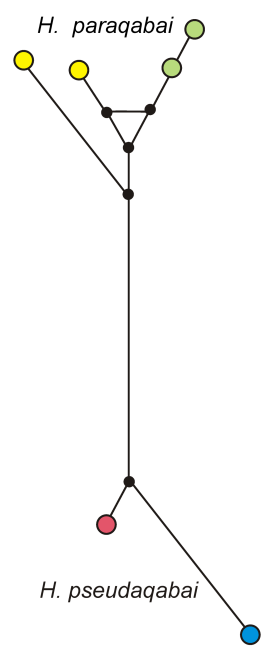

Fig. 11. Results of molecular analyses of Hamodactylus spp. A. Phylogenetic tree resolved by Maximum Likelihood based on COI sequence data with the HKY $+\mathrm{I}+\mathrm{G}$ substitution model (bootstrap values are expressed as percentages in the order ML/BI; GenBank accession numbers are provided for all specimens; newly described species are in bold). B. Median-joining haplotype network showing phylogenetic relationships among haplotypes of the COI gene of two new species of Hamodactylus (yellow colour denotes haplotypes sampled in Madang Lagoon, Papua New Guinea; green in Lizard Island, Australia; blue in Sabah, Malaysia; red in Sulawesi, Indonesia); small black circles represent missing (hypothesised) haplotypes to connect existing sequences within the network with maximum parsimony. 
dorsally dentate and highly arched rostrum, although not always as high as in Hamodactylus, is present in, e.g., Propontonia pellucida Bruce, 1969 and in some species of the genera Periclimenes Costa, 1844, Phycomenes Bruce, 2008 and Zenopontonia Bruce, 1975. The reduced molar process of the mandible is described, e.g., for the genera Ctenopontonia Bruce, 1979, Fennera Holthuis, 1951, Leptomenaeus Bruce, 2007, Metapontonia Bruce, 1967, Nippontonia Bruce \& Bauer, 1997 and Paratypton Balss, 1914 (e.g., Bruce 1967, 1979, 1994, 2007, 2008; Duriš \& Horká 2008). Moreover, the simple walking dactyli, usually biunguiculate or specialized in symbiotic shrimps, are frequently present (e.g., Ancylomenes kuboi Bruce, 2010, Periclimenes lepidus Bruce, 1978, P. madreporae Bruce, 1969, or species of the genera Hamopontonia Bruce, 1970a, Platycaris Holthuis, 1952 and Rapipontonia Marin, 2007) (e.g., Bruce 1969, 1970a, 1978, 2010; Marin 2007, 2009). Most peculiar are, however, the denticulate cutting edges on the subspatulate chelae of the first pereiopods. Such structures are known, e.g., in Periclimenoides odontodactylus (Fujino \& Miyake 1968), Pontoniopsis comanthi Borradaile, 1915, in some species of the genus Periclimenaeus Borradaile, 1915, and in all species of the genera Exoclimenella Bruce, 1995, Leptomenaeus, Periclimenella Bruce, 1995 and Zenopontonia (e.g., Borradaile 1915; Bruce 1975; Fujino \& Miyake 1968; Duriš \& Bruce 1995; Duriš et al. 2009). In some species of Hamodactylus (i.e., in $H$. aqabai and both new species) these denticulate laminae are situated on the lateral cutting edge of the fingers, bearing one or more teeth there as well. This combined character is unique among palaemonid shrimps.

Both new species differ from other congeners by the presence of a series of three or more obtuse teeth distally on the cutting edges on fingers of the first pereiopod chela, at the region just under a thin and highly transparent denticulate lamina. A single tooth is present there in H. aqabai (see Bruce \& Svoboda 1983), while the remaining three species have the first pereiopod finger toothless, with the denticulate lamina extending along the whole length of the cutting edges (Bruce 1970b, 1982). In contrast, the lamina in the other species of Hamodactylus is short, occupying the distal third of the cutting edge.

Both new species may easily be distinguished from H. boschmai by the absence of a supraorbital tooth on the carapace, the presence of which in H. boschmai is unique among known Hamodactylus species. Similarly unique is $H$. macrophthalmus with its long eyes, far overreaching a very short rostrum (Fransen \& Rauch 2013), while the other species have stout eyes distinctly failing to reach the end of the rostrum. Hamodactylus noumeae is the only species in the genus which possesses normally developed chelae on the reduced second pereiopods, with equally grown fingers (Bruce 1970b); the chelae of H. macrophthalmus also have subequal fingers, but they are styliform, with long apical setae, (i.e., 'atyid-like', according to Fransen \& Rauch 2013), and, thus, highly modified from normally developed chelae.

Hamodactylus aqabai differs from H. paraqabai sp. nov. by the longer denticulate lamina and a single tooth distally on the second pereiopod fingers (see above), the multidenticulate distolateral angle of the basal antennular article consisting usually of 4 denticles and by the presence of only one pair of dorsal telson spines. Hamodactylus pseudaqabai sp. nov. shares the two latter characters of the antennule and the telson with H. aqabai (Bruce \& Svoboda 1983).

Summarising the above comparisons, H. paraqabai sp. nov. is most similar to H. pseudaqabai sp. nov. The main morphological differences between these two species are as follows: (1) the fixed finger of the second pereiopod is fully reduced, lacking, in H. paraqabai sp. nov. (vs the fixed finger reduced to a small but distinct stub in H. pseudaqabai sp. nov.); (2) the dactylus of the second pereiopod is long and slender, about 5 times as long as high basally (vs more stout, about 3.5 times as long as high basally); (3) the basal segment of the antennular peduncle has the distolateral margin bidentate, with a small, pointed lobe more mesially (vs a multidentate distolateral margin with up to 4 teeth and a rounded lobe more mesially); (4) the telson bears 2 pairs of small dorsal telson spines (vs only the proximal pair being 
present). In addition to these characters, the adult female of $H$. paraqabai sp. nov. has the posterior dorsum of the carapace slightly swollen, while a female of $H$. pseudaqabai sp. nov. is distinctly gibbous in that place. The first gonopod of the male of H. paraqabai sp. nov. has the endopod elongate, slightly enlarged distally, but the endopod in H. pseudaqabai sp. nov. is broadly ovoid distally.

Actually, the known species of Hamodactylus differ also geographically: H. boschmai and H. noumeae are widely distributed throughout the Indo-West Pacific area, while H. aqabai is the westernmost species, known only from the northern Red Sea; H. macrophthalmus and H. pseudaqabai sp. nov. occupy the central IWP region, being known from Indonesia and Malaysia; and H. paraqabai sp. nov. occurs in seas around Papua New Guinea and northeastern Australia.

Based on the present molecular analyses of known Hamodactylus species, both new species are closely related and have separated from a common ancestor quite recently, which, together with their geographical proximity, is confirmed by the synapomorphic state of the multidentate distal cutting edge on the fingers of the first pereiopod. The distal denticulate lamina on those fingers is a character shared with their closest sister taxon from the Red Sea, H. aqabai. From the present pair of new species, $H$. pseudaqabai sp. nov. is more similar to $H$. aqabai, sharing with it the level of reduction of the second pereiopod chela (to a small but distinct stub, vs full reduction in $H$. paraqabai sp. nov.) and the reduction of the dorsal telson spines to a single proximal pair.

Hamodactylus noumeae, as the basal member of the 'aqabai' lineage, possesses laterally compressed dactyli on the walking legs, and has the fingers of the first pereiopod chelae bearing a long denticulate lamina occupying almost the whole length of the otherwise unarmed cutting edges. Those characters might be regarded as plesiomorphic, being shared with $H$. boschmai, a member of the second genetic lineage of Hamodactylus.

Hamodactylus boschmai and H. macrophthalmus are remarkably different from the quite uniformly built members of the above mentioned 'aqabai' clade. Hamodactylus boschmai possesses supraorbital teeth on the carapace, as well as strongly hooked dactyli overhanging the half-reduced fixed finger on the second pereiopod chela. The latter leg is not noticeably reduced in size. This also confirms the basal position of this species in the actual two-member clade. Hamodactylus macrophthalmus shares with H. boschmai the elongate lamina on the first pereiopod fingers; the pectination of H. macrophthalmus is, however, feebly developed (Fransen \& Rauch 2013: fig. 4A). Based on a comparison of the COI sequences, the latter species is genetically most advanced resulting, among others, into the unique eye elongation and the strongly shortened rostrum, and by the modification of the second pereiopods chelae into the 'atyid-like' shape as noted above. The level of size reduction of the second pereiopod as well as the elongate, slender walking dactyli, are comparable with those of the 'aqabai' clade members (excluding H. noumeae with regards to the later character, see above). The size and shape reduction of the second pereiopods is, however, most advanced in the three terminal members of the 'aqabai' clade, i.e., H. aqabai, H. pseudaqabai sp. nov., and $H$. paraqabai sp. nov. Both the new species are evidently derivates of the most modern cleavage within the known species of the genus resulting in comparatively low molecular divergence on the low end of the commonly used 3-5\% p-distance approach for delimiting species. Nevertheless, their morphological distinctions, particularly in the key morphological characters (below), are in good conformity with the basally well supported molecular divergence of these two species in the present molecular (BI) analysis.

The haplotype network analysis provides more details on the molecular divergence between the new species, confirming together with that their closer phylogenetic relationship, and into their intraspecific haplotype variability. While the COI sequences of the two Australian specimens analysed are almost identical, their conspecific specimens from Papua New Guinea show a wider molecular divergence. 
The number of specimens analysed is, however, too low to provide a more adequate insight into the haplotype variability covered by those two species.

Thanks to the discovery of the two new species, the number of species in the genus Hamodactylus increased by $50 \%$, now comprising six species. A key for their identification is proposed here.

Key for the species identification of adult specimens of the genus Hamodactylus Holthuis, 1952 (modified from Fransen \& Rauch 2013)

1. Carapace with supra-orbital tooth; dactylus of second pereiopod strongly hooked (fixed finger short, up to half length of dactylus) .................................... H. boschmai Holthuis, 1952

- Carapace without supra-orbital tooth; dactylus of second pereiopod feebly curved, not hooked ......2

2. Second pereiopod with fixed finger of chela about as long as dactylus; first pereiopod with denticulate lamina along almost whole cutting edge of dactylus ............................... 3

- Second pereiopods non-chelate, with fixed finger reduced to small stub or completely lacking; first pereiopod with denticulate lamina on distal $1 / 3$ of dactylus .............................. 4

3. Anteriorly extended eyes shorter than rostrum; eyestalk short, about as long as wide; basal segment of antennular peduncle with 2-3 teeth on distolateral margin ...H. noumeae Bruce, 1970b

- Anteriorly extended eyes far overreaching rostrum; eyestalk long, about twice as long as wide; basal segment of antennular peduncle with one distolateral tooth. ....

H. macrophthalmus Fransen \& Rauch, 2013

4. Fixed finger of second pereiopod fully reduced, lacking; telson with 2 pairs of dorsal spines; basal segment of antennular peduncle with distolateral margin bidentate (cutting edges of first pereiopod with $3-5$ teeth on distal $1 / 3) \ldots \ldots \ldots \ldots \ldots \ldots \ldots \ldots \ldots \ldots \ldots \ldots \ldots \ldots \ldots \ldots$. paraqabai sp. nov.

- Fixed finger of second pereiopod reduced to small but distinct stub; telson with 1 pair of dorsal spines; basal segment of antennular peduncle with multidentate distolateral margin (4 teeth, 1-2

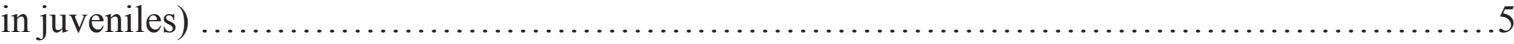

5. Cutting edges of first pereiopod fingers with 1 tooth on distal $1 / 3$; ventral rostral margin convex H. aqabai Bruce \& Svoboda, 1983

- Cutting edges of first pereiopod fingers with 3-4 teeth on distal 1/3; ventral rostral margin straight H. pseudaqabai sp. nov.

\section{Acknowledgements}

The material was collected during the following expeditions: (1) CReefs Lizard Island Expedition 2010, a part of the CReefs Australia - a partnership between the Australian Institute of Marine Science, BHP Billiton, the Census of Marine Life, and the Great Barrier Reef Foundation project (principal investigators : J. Caley and S. Smith, AIMS, Townsville); (2) Madang, 2012, part of Our Planet Reviewed, Papua Niugini Expedition, organized jointly by the MNHN, Pro Natura International, the Institut de Recherche pour le Développement, and the University of Papua New Guinea (principal investigators: P. Bouchet, S. Samadi, and C. Payri); funded by the Total Foundation, Prince Albert II of Monaco Foundation, Foundation EDF, Stavros Niarchos Foundation, and Entrepose Contracting; supported by the Divine Word University, permit delivered by the Papua New Guinea Department of Environment and Conservation; (3) Rumphius Biohistorical Expedition to Ambon, Indonesia, 1990, organized jointly by the Nationaal Natuurhistorisch Museum Leiden (NNM) (presently Naturalis Biodiversity Center), Lembaga Ilmu Pengetahuan Indonesia (LIPI), Pattimura University Ambon (principal investigator: H.L Strack); (4) Sulawesi Expedition, 1994, organized jointly by the NNM and LIPI (principal investigator J. van der Land); (5) Maluku Expedition to Ambon and Seram, 1996, organized jointly by the NNM and 
LIPI (principal investigator: J. van der Land); (6) Semporna Marine Ecological Expedition to Semporna, Malaysia, 2010, was organized jointly by WWF-Malaysia, Universiti Malaysia Sabah's Borneo Marine Research Institute, Netherlands Centre for Biodiversity Naturalis (Presently Naturalis Biodiversity Center) and Universiti Malaya's Institute of Biological Sciences; research permission was granted by Economic Planning Unit, Prime Minister's Department, Economic Planning Unit Sabah, Sabah Parks and Department of Fisheries Sabah (principal investigators: B.W. Hoeksema and Z. Waheed); (7) Marine Biodiversity Workshop Lembeh Strait, 2012, jointly organized by the Universitas Sam Ratulangi (UNSRAT in Manado), the Bitung field station of the Research Centre of Oceanography (PPO-LIPI), and Naturalis Biodiversity Center (principal investigators: M.T. Lasut, B.W. Hoeksema and Y. Tuti).

The authors are grateful to Dr. L.P. van Ofwegen (Naturalis Biodiversity Center, Leiden) for identification of alcyonacean corals, and to two anonymous reviewers for valuable comments and proposals to the manuscript. This work was supported by the project CZ.1.05/2.1.00/03.0100 (IET), financed by the Structural Funds of the European Union, and by project LO1208 of the National Feasibility Programme-I of the Czech Republic (Z.D..).

\section{References}

Bandelt H.J., Forster P. \& Röhl A. 1999. Median-joining networks for inferring intraspecific phylogenies. Molecular Biology and Evolution 16(1): 37-48.

Borradaile L.A. 1915. Notes on Carides. The Annals and Magazine of Natural History, series 8: 205213. http://www.biodiversitylibrary.org/item/53307\#page/225/

Bruce A.J. 1967. Notes on some Indo-Pacific Pontoniinae, III-IX. Descriptions of some new genera and species from the Western Indian Ocean and the South China Sea. Zoologische Verhandelingen 87: 1-73.

Bruce A.J. 1969. Preliminary descriptions of sixteen new species of the genus Periclimenes Costa, 1844 (Crustacea, Decapoda Natantia, Pontoniinae). Zoologische Mededelingen 43: 253-278.

Bruce A.J. 1970a. Notes on some Indo-Pacific Pontoniinae. XV. Hamopontonia corallicola gen. nov., sp. nov., a new pontoniid shrimp from Hong Kong. Crustaceana 18: 37-48. http://dx.doi. org/10.1163/156854070X00040

Bruce A.J. 1970b. Report on some commensal pontoniid shrimps (Crustacea: Palaemonidae) associated with an Indo-Pacific gorgonian host (Coelenterata: Gorgonacea). Journal of Zoology 160: 537-544. http://dx.doi.org/10.1111/j.1469-7998.1970.tb03096.x

Bruce A.J. 1975. Notes on some Indo-Pacific Pontoniinae, XXV. Further observations upon Periclimenes noverca Kemp, 1922, with the designation of a new genus Zenopontonia, and some remarks upon Periclimenes parasiticus Borradaile (Decapoda Natantia, Palaemonidae). Crustaceana 28: 275-285. http://dx.doi.org/10.1163/156854075X00531

Bruce A.J. 1978. A report on a collection of pontoniine shrimps from Madagascar and adjacent seas. Zoological Journal of the Linnean Society 62: 205-290. http://dx.doi.org/10.1111/j.1096-3642.1978. tb01039.x

Bruce A.J. 1979. Ctenopontonia cyphastreophila, a new genus and species of coral associated pontoniine shrimp from Eniwetok Atoll. Bulletin of Marine Science 29(3): 423-435.

Bruce A.J. 1981. Pontoniine shrimps of Heron Island. Atoll Research Bulletin 245: 1-33.

Bruce A.J. 1982. The pontoniine shrimp fauna of Hong Kong. In: Morton B.S. \& Tseng C.K. (eds) The Marine Flora and Fauna of Hong Kong and Southern China. Proceedings of the First International Marine Biological Workshop: 233-284. Hong Kong University Press, Hong Kong.

Bruce A.J. 1983. The pontoniine shrimp fauna of Australia. Australian Museum Memoir 18: 195-218. 
HORKÁ I. et al., Two new species of Hamodactylus (Palaemonidae)

Bruce A.J. 1994. A Synopsis of the Indo-West Pacific Genera of the Pontoniinae (Crustacea: Decapoda: Palaemonidae). Theses Zoologicae 25, Koeltz Scientific Books, Königstein.

Bruce A.J. 2007. Leptomenaeus gen. nov., a new name for Leptomenes Bruce, 2006 (Crustacea: Decapoda: Pontoniinae). Cahiers de Biologie Marine 48: 411-412.

Bruce A.J. 2008. Phycomenes zostericola gen. nov., sp. nov., a new pontoniine shrimp (Crustacea: Decapoda: Palaemonidae) from Moreton Bay, Queensland. In: Davie P.J.F. \& Phillips J.A. (eds) The Marine Fauna and Flora of Moreton Bay, Queensland. Proceedings of the Thirteenth International Marine Biological Workshop, Memoirs of the Queensland Museum - Nature 54(1): 219-232. Brisbane.

Bruce A.J. 2010. Ancylomenes kuboi and A. okunoi spp. nov. (Decapoda: Pontoniinae), from the Australian Northwest Shelf, Vietnam and the Philippines. Zootaxa 2372: 169-176.

Bruce A.J. \& Svoboda A. 1983. Observations upon some pontoniine shrimps from Aqaba, Jordan. Zoologische Verhandelingen 205: 1-44.

Chace F.A. Jr. \& Bruce A.J. 1993. The caridean shrimps (Crustacea: Decapoda) of the Albatross Philippine Expedition, 1907-1910, Part 6: Superfamily Palaemonoidea. Smithsonian Contributions to Zoology 543: 1-151. http://dx.doi.org/10.5479/si.00810282.543

Darriba D., Taboada G.L., Doallo R. \& Posada D. 2012. jModelTest 2: more models, new heuristics and parallel computing. Nature Methods 9 (8): 772. http://dx.doi.org/10.1038/nmeth.2109

Duriš Z. \& Bruce A.J. 1995. A revision of the 'petitthouarsii' species-group of the genus Periclimenes Costa, 1844 (Crustacea: Decapoda: Palaemonidae). Journal of Natural History 29(3): 619-671. http:// dx.doi.org/10.1080/00222939500770221

Ďuriš Z. \& Horká I. 2008. A new shrimp species of the genus Leptomenaeus Bruce, 2007 (Crustacea: Decapoda: Pontoniinae) from Vietnam. Zootaxa 1872: 45-58.

Ďuriš Z., Horká I. \& Sandford F. 2009. Periclimenaeus pectinidactylus n. sp. (Crustacea: Decapoda: Pontoniinae) from the Belizean Barrier Reef, Caribbean Sea. Zootaxa 2130: 31-40.

Edgar R.C. 2004. MUSCLE: multiple sequence alignment with high accuracy and high throughput. Nucleic Acids Research 32: 1792-1797. http://dx.doi.org/10.1093/nar/gkh340

Folmer O., Black M., Hoeh W., Lutz R. \& Vrijenhoek R. 1994. DNA primers for amplification of mitochondrial cytochrome $c$ oxidase subunit I from diverse metazoan invertebrates. Molecular Marine Biology and Biotechnology 3(5): 294-299.

Fransen C.H.J.M. 2012. Palaemonid Shrimps. In: Kassem K., Hoeksema B. \& Affendi Y.A. (eds) Semporna Marine Ecological Expedition: 101-108. WWF-Malaysia, NCB Naturalis; Universiti Malaysia Sabah. Kota Kinabalu, Malaysia.

Fransen C.H.J.M. \& Rauch C. 2013. Hamodactylus macrophthalmus spec. nov., a new coral-associated pontoniine shrimp (Decapoda, Caridea, Palaemonidae) from Indonesia. Zootaxa 3635(3): 286-296. http://dx.doi.org/10.11646/zootaxa.3635.3.8

Fujino T. \& Miyake S. 1968. Description of two new species of pontoniid shrimps (Crustacea, Decapoda, Palaemonidae) commensal with sponges. Ohmu. Occasional papers of the Zoological Laboratory, Faculty of Agriculture, Kyushu University 1: 85-96.

Marin I. 2007. Pontoniine shrimps (Decapoda: Caridea: Palaemonidae) inhabiting boring sponges (Porifera: Demospongia) from Nhatrang Bay, Vietnam, with descriptions of three new species. Zoologische Mededelingen 81: 217-240.

Marin I. 2009. A review of the pontoniine shrimp genus Rapipontonia Marin, 2007 (Decapoda: Caridea: Palaemonidae), with the description of a new species from the Indo-West Pacific. Zootaxa 2289: 1-17. 
Miller M.A., Pfeiffer W. \& Schwartz T. 2010. Creating the CIPRES Science Gateway for inference of large phylogenetic trees. In: Proceedings of the Gateway Computing Environments Workshop (GCE), 14 Nov. 2010, New Orleans, LA: 1-8.

Ronquist F., Teslenko M., van der Mark P., Ayres D.L., Darling A., Höhna S., Larget B., Liu L., Suchard M.A. \& Huelsenbeck J.P. 2012. MrBayes 3.2: efficient Bayesian phylogenetic inference and model choice across a large model space. Systematic Biology 61: 539-542. http://dx.doi.org/10.1093/sysbio/ sys029

Tamura K., Stecher G., Peterson D., Filipski A. \& Kumar S. 2013. MEGA6: Molecular Evolutionary Genetics Analysis version 6.0. Molecular Biology and Evolution 30(12): 2725-2729. http://dx.doi. org $/ 10.1093 / \mathrm{molbev} / \mathrm{mst} 197$

Manuscript received: 7 September 2015

Manuscript accepted: 2 December 2015

Published on: 6 April 2016

Topic editor: Rudy Jocqué

Desk editor: Kristiaan Hoedemakers

Printed versions of all papers are also deposited in the libraries of the institutes that are members of the EJT consortium: Muséum national d'Histoire naturelle, Paris, France; Botanic Garden Meise, Belgium; Royal Museum for Central Africa, Tervuren, Belgium; Natural History Museum, London, United Kingdom; Royal Belgian Institute of Natural Sciences, Brussels, Belgium; Natural History Museum of Denmark, Copenhagen, Denmark. 